REVISTA DE DERECHO UNED, NÚM. 18, 2016

\title{
LOS SUPUESTOS DE RESPONSABILIDAD TRIBUTARIA SUBSIDIARIA EN EL PAGO DE LAS SANCIONES TRIBUTARIAS PREVISTOS EN EL ARTÍCULO 43 DE LA LEY 58/2003, DE 17 DE DICIEMBRE, GENERAL TRIBUTARIA (LGT)
}

\author{
CASES OF SUBSIDIARY TAX LIABILITY IN THE PAYMENT \\ OF THE TAX SANCTIONS FORESEEN IN THE ARTICLE 43 \\ OF THE LAW 58/2003, OF DECEMBER 17, GENERAL \\ TRIBUTARIA (LGT)
}

IVÁN PÉREZ JORDÁ

Funcionario de Administración Local con habilitación de carácter nacional. Doctor en Derecho Financiero y Tributario

Resumen: El presente artículo analiza y expone el estado de la cuestión en relación a los tres supuestos de responsabilidad tributaria subsidiaria en el pago de las sanciones tributarias desde la óptica, que defendemos, del principio de personalidad de la sanción, pues venimos defendiendo que esa responsabilidad tributaria no conforma sino una subespecie de sanción impropia que, lejos de ser meras garantías del cobro de la sanción tributaria impuesta a un tercero, son consecuencia de la realización de una conducta ilícita que conforma tipos de responsabilidad tributaria y no son sino tipos infractores impropios, cuya regulación debe ser analizada a la luz de los principios del derechos administrativo-tributario sancionador y, en su caso, del derecho penal. Pese a que no resulte el objeto de este artículo, debemos resaltar que estas sanciones impropias deberán imponerse a través de un procedimiento que, bajo el prisma de los principios de culpabilidad, personalidad de la pena o sanción, (autoría, participa- 
ción), capacidad económica y derecho a la presunción de inocencia, esté dotado de garantías análogas a las del sancionador tributario, pues idéntica es la naturaleza sancionadora del instituto de la responsabilidad tributaria.

Abstract: This article analyzes and examines the question relating to the three suppositions of subsidiary tax liability in the payment of tributary sanctions from the standpoint of the personality of the sanction principle. We defend that this tributary responsibility does not form only a subdivision of improper sanctions that, far from being mere guarantees of the collection of the tributary sanction imposed on a third party, are a consequence of the illicit action that conform types of tax liability and are not only types of improper infractions, whose regulation should be studied in the light of the principle of administrative, tributary law and, if appropriate, the application of criminal law. Despite not being the principal object of this article, we must highlight that these improper sanctions would need to be imposed using a procedure that, under the prism of the principle of guilt, personal punishment or sanction, (authorship, participation), economic capacity and right to the presumption of innocence, provides for comparable guarantees to those of the tributary sanction procedure, as the sanctioning nature of the institute of the tax liability is identical.

Palabras clave: Responsabilidad tributaria, sanción tributaria subsidiaria.

Keywords: Tax liability, subsidiary tax sanction.

Recepción original: 28/12/2015

Aceptación original: 6/04/2016

Sumario: I. Supuestos previstos de responsabilidad tributaria subsidiaria en el pago de las sanciones tributarias: Introducción. II. El supuesto del apartado a) del artículo 43.1 LGT. III. Los supuestos de los apartados g) y h) del artículo 43.1 LGT. 


\section{SUPUESTOS PREVISTOS DE RESPONSABILIDAD TRIBUTARIA SUBSIDIARIA ${ }^{1}$ EN EL PAGO DE LAS SANCIONES TRIBUTARIAS: INTRODUCCIÓN}

En la elección responsabilidad subsidiaria-responsabilidad solida$\mathrm{ria}^{2}$ el legislador tributario debe manifestar una preferencia radical, por no decir exclusiva o no compartida, por el responsable subsidiario $^{3}$ frente al responsable solidario. Pues sólo el responsable subsidiario, entiendo, compatibiliza adecuadamente el fin de aseguramiento que se persigue en el responsable con el requerimiento de que sea el infractor quien peche y cumpla las consecuencias de su infracción tributaria. Sólo el responsable subsidiario fuerza a la Administración a agotar todas las posibilidades de pago del contribuyente antes de exigir el pago al responsable 4 .

Es nuestro parecer que, quien sea sancionado a título de infractor por incumplimientos legalmente tipificados, en modo alguno se podrá

${ }^{1}$ En opinión del profesor FERREIRO LAPATZA, «en la elección responsabilidad subsidiaria responsabilidad solidaria el legislador tributario debe manifestar una preferencia radical, por no decir exclusiva o no compartida, por el responsable subsidiario frente al responsable solidario. Pues sólo el responsable subsidiario, entiendo, compatibiliza adecuadamente el fin de aseguramiento que se persigue en el responsable con el principio de personalidad de la pena que requiere que sea el infractor quien pague. Sólo el responsable subsidiario fuerza a la Administración a agotar todas las posibilidades de pago del infractor antes de exigir el pago al responsable». FERREIRO LAPATZA, J. J.: « «Reflexiones sobre Derecho tributario y técnica jurídica», $R E D F$, núm. 85, 1993. pág. 42.

${ }^{2}$ Aunque no pueda colegirse un concreto argumento que permita indicar un factor diferencial entre una u otra tipología, como podría ser la inmediatez en la comisión. Checa González, C.: Los Responsables Tributarios, Thomson-Aranzadi, Madrid, 2003, pág. 29.

${ }^{3}$ La LGT establece como norma general la responsabilidad subsidiaria, que se adecua mejor al principio de capacidad económica y de justicia tributaria que la responsabilidad solidaria, ya que es necesaria la previa declaración de fallido del contribuyente. Este requisito se complementa con la facultad que acertadamente se concede a los responsables de alegar en cualquier momento lo que estimen conveniente con carácter previo al trámite de audiencia. En el caso de la responsabilidad subsidiaria, el responsable podrá señalar bienes del contribuyente, exigir de la Administración una mayor diligencia en el cobro de sus créditos y denunciar comportamientos del contribuyente que puedan conducir al vaciado de su patrimonio en perjuicio del responsable. Por el contrario, la responsabilidad solidaria, (...) puede atentar contra el principio de capacidad económica siempre que no consiga el responsable, a través de la correspondiente acción de regreso contra el contribuyente, el reembolso de la cantidad pagada. Como este tipo de responsabilidad no requiere la previa declaración de fallido del contribuyente, todo depende del éxito (muchas veces difícil) de la citada acción. Si no tiene un resultado satisfactorio, se puede llegar a una situación tan absurda e injusta como que pague la obligación tributaria quien no ha manifestado capacidad económica alguna (...)». CALVO ORTEGA, R.: El Proyecto de Ley General Tributaria: aportaciones y aspectos críticos, Rev. Nueva Fiscalidad, núm. 7, págs. 39, 40, 43 y 44.

${ }^{4}$ FERREIRO LAPATZA, J. J.: «Reflexiones ...op. cit. pág. 42. 
convertir en responsable tributario subsidiario del pago de sanción alguna ${ }^{5}$, pues una cosa supone responder a título de infractor (u obligado principal) y otra a título de responsable tributario del pago de la sanción impuesta al infractor. Aún más, no es idéntica la obligación solidaria de pago de la sanción entre infractores tributarios (art. 181.3 LGT), que la responsabilidad del pago de sanciones tributarias (art. 182 LGT) a la que hacen frente los responsables tributarios (arts. 41 a 43 LGT). Y por el contrario, la determinación del responsable tributario $^{6}$ en estos supuestos quiebra principios tan esenciales en el ámbito sancionador como los de necesaria concurrencia de culpabilidad ${ }^{7}$, personalidad de la pena ${ }^{8}$, capacidad económica ${ }^{9}$ o proporcionalidad, o derecho a la presunción de inocencia, pues se responderá de la sanción tributaria de un tercero.

De conformidad con lo preceptuado en el art. 182.2 LGT, responderán subsidiariamente del pago de las sanciones tributarias las personas o entidades que se encuentren en los supuestos de los párrafos a), g) y h) del apartado 1 del artículo 43 de esta Ley, en los términos establecidos en dicho artículo. Así, lo serán las personas o entidades,

${ }^{5} \mathrm{Ni}$ el carácter ilícito de un comportamiento justifica la obligación de pagar la sanción impuesta a otra persona por una conducta distinta, ni quien impide la ejecución forzosa del importe correspondiente a una sanción tributaria está causando a la Administración un daño patrimonial que pueda ser obligado a compensar o indemnizar. GONZÁLEZ ORTIZ, D.: La responsabilidad tributaria en el ordenamiento jurídico español, Dykinson, Madrid, 2002, pág. 143.

${ }^{6}$ En todo caso... el haber colaborado en una infracción, si la ley no lo dispone expresamente, no alcanzará a las sanciones. Por tanto, se rompe con la relación consistente en actitud ilícita y responsabilidad por la sanción de tal manera que no toda conducta contraria a Derecho conlleva responsabilidad por las sanciones. BLÁZQUEZ LIDOY, A.: Novedades de la Ley General Tributaria 58/2003 en la regulación de la responsabilidad tributaria y de la sucesión, Centro de Estudios Financieros, Revista de Contabilidad y Tributación, núm. 255, 38/2004, pág. 8 .

${ }^{7}$ Debe rechazarse la asunción por parte del responsable de la sanción impuesta al obligado principal no habiendo participado aquél en su generación. Y ello sucederá en tanto en cuanto la infracción ya haya sido cometida en el instante en el que se realice el presupuesto de hecho de la responsabilidad. GONZÁLEZ ORTIZ, D.: La responsabilidad tributaria ...op. cit., pág. 143.

${ }^{8}$ Admitiendo la exigencia de las mismas a aquellos responsables que hubieran participado en la comisión de la infracción, MARTÍN FERNÁNDEZ, J.: La reforma de la Ley General Tributaria por la Ley de Medidas para la Prevención del Fraude Fiscal, Estudios de Derecho Judicial, núm. 140, 2007, pág. 114; ÁLVAREZ MARTÍNEZ, J.: El alcance de la responsabilidad tributaria en la nueva Ley General Tributaria: análisis y examen comparativo respecto de la Ley General Tributaria de 1963, Revista de Contabilidad y Tributación, núm. 263, 2005, págs. 40 y ss.

${ }^{9} \mathrm{Al}$ soportar la deuda o sanción del deudor o infractor principal, sin que pueda resarcirse, en la mayor parte de ocasiones, del mismo, pechando con el total importe de la responsabilidad, dejando a su elección, y a través de la jurisdicción ordinaria, la posibilidad de repetir contra el resto de obligados y responsables, lo abonado él. 
sin perjuicio de lo dispuesto en el párrafo a) del apartado 1 del artículo 42 de esta ley, (a) administradores de hecho o de derecho de las personas jurídicas que, habiendo éstas cometido infracciones tributarias, no hubiesen realizado los actos necesarios que sean de su incumbencia para el cumplimiento de las obligaciones y deberes tributarios, hubiesen consentido el incumplimiento por quienes de ellos dependan o hubiesen adoptado acuerdos que posibilitasen las infracciones. Su responsabilidad también se extenderá a las sanciones. (g) Las personas o entidades que tengan el control efectivo, total o parcial, directo o indirecto, de las personas jurídicas o en las que concurra una voluntad rectora común con éstas, cuando resulte acreditado que las personas jurídicas han sido creadas o utilizadas de forma abusiva o fraudulenta para eludir la responsabilidad patrimonial universal frente a la Hacienda Pública y exista unicidad de personas o esferas económicas, o confusión o desviación patrimonial. La responsabilidad se extenderá a las obligaciones tributarias y a las sanciones de dichas personas jurídicas. (h) Las personas o entidades de las que los obligados tributarios tengan el control efectivo, total o parcial, o en las que concurra una voluntad rectora común con dichos obligados tributarios, por las obligaciones tributarias de éstos, cuando resulte acreditado que tales personas o entidades han sido creadas o utilizadas de forma abusiva o fraudulenta como medio de elusión de la responsabilidad patrimonial universal frente a la Hacienda Pública, siempre que concurran, ya sea una unicidad de personas o esferas económicas, ya una confusión o desviación patrimonial. En estos casos la responsabilidad se extenderá también a las sanciones.

Las leyes podrán establecer otros supuestos ${ }^{10}$ de responsabilidad subsidiaria distintos de los previstos en el apartado anterior, lo que se compadece mal con el propio carácter de Ley General de la LGT. No se aplicará el instituto de la responsabilidad subsidiaria en el pago de sanciones tributarias en el caso del derecho de afección de bienes (art. 79 LGT).

Los supuestos de responsabilidad, en algunos casos, en concreto los del art. 43.2 LGT (subsidiaria), introducido por la Ley 7/2012, -donde no existe responsabilidad por sanciones-y los de los

${ }^{10}$ A salvo de la existencia de otros supuestos de responsables subsidiarios establecidos por las Leyes, los específicamente recogidos, a simple título ejemplificativo, en el artículo 43 del ALGT son los siguientes:... CHECA GONZÁLEZ, C.: Notas sobre la nueva regulación de los responsables tributarios en el anteproyecto de la LGT, Jurisprudencia Tributaria, Aranzadi núm.5/2003, BIB 2003\702. 
apartados a) y b) ${ }^{11}$ del art. 43.1. ${ }^{\circ}$ LGT (subsidiaria), junto a los del art. 42.1.a) y 42.2 LGT (solidaria) ${ }^{12}$, vendrán a yuxtaponerse a los ya existentes contenidos en la LGT que afectan a los administradores sociales, pero sin que exista solapamiento con ellos, sin perjuicio de la posibilidad de encontrar casos en los que se produzca una concurrencia real de normas sobre unos mismos hechos ${ }^{13}$.

\section{EL SUPUESTO DEL APARTADO A) DEL ARTÍCULO 43.1 LGT}

Respecto del supuesto previsto en el art. 43.1.a) ${ }^{14}$ LGT, con anterioridad recogido en el art. 40.1 LGT $1963^{15}$, no se advera la exigencia de dolo en todos los supuestos, sino que parece como si cobijase supuestos de culpa ${ }^{16}$-como el supuesto de falta de realización de actos

${ }^{11}$ El único supuesto, pues, donde no se produce la extensión de la responsabilidad a las sanciones es el de los administradores de las personas jurídicas que cesan en sus actividades dejando deudas tributarias pendientes -art. 43.1.b)-. La exclusión de las sanciones en este último supuesto es indiscutible, toda vez que la conducta del administrador, aunque negligente, no alcanza la gravedad necesaria para constituir una infracción tributaria. Pero en los casos de colaboración en alguna infracción, la LGT/2003 entiende que en estos casos pueden exigirse las sanciones porque no se produce ningún tipo de vulneración del principio de personalidad de la sanción, toda vez que el responsable ha colaborado en el ilícito. Martínez Micó, J. G.: El alcance de la responsabilidad tributaria de los administradores de sociedades: su extensión a las sanciones, Quincena Fiscal, núm. 22/2009, BIB 2009\1839.

${ }^{12}$ En relación a la eficacia de esta nueva norma, SÁNCHEZ PEDROCHE ha señalado que la regulación ahora comentada comportará efectos indeseados en la práctica, pues «se trasladará la responsabilidad nuevamente hacia los artículos 42.1 a) y 43.1 a) LGT. SÁNCHEZ PEDROCHE, J. A.: Primeras y preocupantes impresiones sobre el Anteproyecto de Ley de modificación de la normativa tributaria y presupuestaria para la lucha contra el fraude, Quincena Fiscal, núm. 11, 2012, pág. 105.

${ }^{13}$ CAYÓN GALIARDO, A.: La lucha contra el fraude en la Ley 7/2012. ...op. cit. pág. 20.

${ }^{14}$ Siendo, pues, apreciable la distancia sustantiva que media entre un supuesto (art. 42.1.a GLT) y otro (art.43.1.a LGT) naciendo un caso de la infracción y el otro de la deuda impagada lo cierto y verdad es que no es tan acusada la diferencia fáctica entre los presupuestos de hecho que dan lugar al nacimiento de la responsabilidad en cada caso. Causar o colaborar en la infracción, omitir la debida diligencia, consentir el incumplimiento o posibilitar su realización no son comportamientos tan distintos que permitan su nítida identificación y prueba en la realidad del actuar societario. Rozas Valdés, J. A.: La responsabilidad fiscal de los administradores, trabajos del Grup de Recerca sobre Govern Corporatiu de l'Empresa de la Generalitat de Cataluña (2005SGR00820), coord. Prof. Vázquez Albert, D., Barcelona, 2008, pág. 13.

${ }^{15}$ ARIAS ABELLAN, M. ${ }^{\mathrm{a} D}$.: «Modificaciones ...op. cit. págs. 426-427.

${ }^{16}$ En algún momento, concretamente antes de la reforma del artículo 37 de la LGT por la Ley 10/1985, de 26 de abril, se exigía a estos fines la necesidad de mala fe o negligencia grave en la conducta del administrador, exigencias que desaparecieron de la norma a raíz de referida modificación normativa. Ello no obstante, hay que entender, y esto es plenamente aplicable tanto a la situación actual como a lo dispuesto por el Anteproyecto de la LGT, que la supresión de la exigencia de mala fe o 
necesarios de su incumbencia para el cumplimiento-, y no excluye de responsabilidad tributaria en el pago de la sanción a «los administradores que no asistieran a la reunión o que salvarán expresamente su voto en los acuerdos de que se trate» (art. 179.2 LGT). El precepto demanda como elementos objetivos, una previa infracción tributaria, y subjetivo ${ }^{17}$, que resulte infractora una persona jurídica ${ }^{18}$, -en cualquier tipo y orden, excluyendo así a las personas carentes de personalidad del art. 35.4 LGT (que carecen de personalidad jurídica aun cuando se les atribuya subjetividad tributaria, dado que dichos entes siguen un régimen jurídico propio de «representación» o administración del conjunto patrimonial)-, no existiendo responsabilidad tributaria del pago de sanción alguna sin previa imposición de sanción a la persona jurídica infractora. A mayor abundamiento, deberá existir un concreto comportamiento ${ }^{19}$ por parte del administrador ${ }^{20}$ societario,

negligencia grave en los administradores «no supone la desaparición de los principios de voluntariedad o de personalidad en su conducta», tal como con acierto se indicó ya en la Resolución del TEAC de 10 julio 1996, con doctrina reiterada, entre otras, en sus posteriores Resoluciones de 12 febrero 1998 y 15 enero 1999. Se ha insistido, igualmente, en esta circunstancia, en, por ejemplo, las Sentencias de la AN de 29 septiembre 1999, del TSJ de Castilla y León de 9 febrero 2000, del TSJ de Aragón de 18 febrero 2000, del TSJ de Cantabria de 21 marzo 2000 y del TSJ de Extremadura de 13 noviembre 2001 y 29 abril 2002, en la que se declaró que: «Los requisitos exigidos por el artículo 40.1 de la LGT son: a) comisión de una infracción tributaria por la sociedad; b) tener la condición de administrador al tiempo de cometerse la infracción; y c) una determinada conducta ilícita del administrador». CHECA GONZÁLEZ, C.: Notas sobre la nueva regulación...op. cit.

${ }^{17}$ Excluyendo a los administradores de los entes públicos en que se organiza el Estado, ni a los administradores de todas las corporaciones de Derecho público, pertenezcan al Estado o no (colegios profesionales, academias, organismos autónomos, etc.). GARRETA SUCH, J. M. : $^{\text {a }}$ La responsabilidad civil, fiscal y penal de los administradores de las sociedades, Madrid, Marcial Pons, 1996, págs. 296-297. En dicho sentido parece que se pronuncia la DA $7 .^{\mathrm{a}} \mathrm{LGT}$.

${ }^{18}$ De modo que a través de una fictio iuris se logra que la voluntad manifestada (a favor de la conducta antijurídica) por personas físicas en los órganos de la persona jurídica sean la propia voluntad de dicha persona jurídica, separadamente de la de sus miembros. Así la STC 246/1991, de 19 de diciembre, de modo que, para el caso de las infracciones administrativas cometidas por personas jurídicas no significa que se haya suprimido el elemento subjetivo de la culpa, sino simplemente que ese principio se ha de aplicar necesariamente de forma distinta a como se hace respecto a las personas físicas.

${ }^{19}$ Responderán tributariamente quienes, actuando como administradores de una persona jurídica, realicen materialmente las conductas tipificadas como infracción tributaria por lo que resulta necesario la investigación del reparto interno de funciones en el ámbito de la empresa, con el fin de delimitar a cuál o cuáles de las personas que pueden ser consideradas administradores incumbía la realización de ciertas actuaciones. ZORNOZA PEREZ, J. J.: El sistema de infracciones y sanciones tributarias, Civitas, Madrid, 1992, pág. 197.

${ }^{20}$ Según Díaz Echegaray, "por administradores de derecho debe entenderse aquellos que habiendo sido designados conforma a las normas legales y estatuta- 
rias, han aceptado dicha designación y la misma ha sido inscrita en los oportunos registros públicos», mientras que con la mención a los administradores de hecho se estaría haciendo referencia, por un lado, a «los que, sin ocupar formalmente cargo alguno, de hecho controlan y gobiernan la sociedad sustituyendo a los administradores o ejerciendo sobre ellos una influencia decisiva», y a «los que ocupando formalmente el cargo de iure no lo ostentan por estar afectado su nombramiento por algún vicio, sea de fondo o de forma». Sin embargo, según este mismo autor, "no cabe incluir dentro de los administradores de hecho a los altos directivos de la sociedad tales como el Director general, gerente, etc., dado que no poseen la naturaleza de órgano social que corresponde a los administradores y que da lugar a que la ley les atribuya un conjunto típico de deberes y facultades». DÍAZ ECHEGARAY, J. L.: La responsabilidad penal de los socios y administradores, Madrid, Editorial Montecorvo, 1997, págs. 97 y ss; Conviene pues advertir, en principio, que la condición de administrador no depende de la denominación que se dé a la persona o cargo sino del efectivo contenido legal o estatutario de sus cometidos, según éstos confieran atribuciones conformadoras de la voluntad social y en definitiva integradas en ella, o sólo supongan una representación, en que la que los actos del sujeto aparecen diferenciados de dicha voluntad social, aunque sean imputables a la entidad a título de representado. El administrador será quien -por sí solo, en unión de otros administradores o integrado colegiada y solidariamente en el Consejo de Administración- gestiona la persona jurídica con autonomía decisoria, realizando actos decisivos para la actividad social, de dirección o disposición, que rebasan la mera administración. Y ello no sólo resulta de ostentar legalmente el cargo orgánico de administrador, pues puede ocurrir que, pese a la notable formalización normativa de la administración de derecho, existan situaciones anómalas -causadas por renuncias, ceses, caducidad del cargo, vicios jurídicos, paralización de órganos societarios u otras circunstancias- en las que el administrador o administradores no existen o son difícilmente determinables, sin que la falta de administrador legal impida el mantenimiento en la persona jurídica de un real y efectivo poder de decisión, incluso con encubrimiento del verdadero administrador -administrador "oculto»- que dirige la entidad o ejerce influencia o control determinante sobre los administradores formalmente designados. Surge así el llamado administrador "de hecho", como noción negativa o contrafigura del de derecho, que se produce en un amplio espectro de situaciones reconducibles a dos grandes tipos: a) el del administrador de hecho, surgido de irregularidades en la atribución o mantenimiento del cargo, cuyo tratamiento jurídico responde al reconocimiento jurídico de la realidad resultante de la apariencia, por razones obvias de seguridad jurídica, y se dirige básicamente a garantizar la continuidad de la empresa; b) el del administrador de hecho, que resulta de una finalidad de mantener indeterminada o encubierta la condición de administrador para eludir la responsabilidad que ésta entraña, con lo que su consideración jurídica atiende dominantemente a evitar o impedir esta elusión. El primer caso es el contemplado tradicionalmente por las normas del derecho común; el segundo es dominantemente atendido por las normas penales (art. $31 \mathrm{CP}$ ) o administrativas sancionadoras, con tendencia a expandirse por todas las ramas del ordenamiento para garantizar la transparencia de la gestión social y los derechos de los terceros que se relacionan con la entidad, abarcando así todos los casos de inexistencia o indeterminación de administradores formal y legalmente nombrados. Lo esencial en estos administradores de hecho es la asunción o realización autónoma de tareas de dirección efectiva de la persona jurídica, de manera habitual y sistemática; es decir, una injerencia decisoria directa - no meramente asesora o coadyuvante- en la gestión directiva de la entidad, de manera duradera y mediante de actos reitera- 
no siendo suficiente con que ocupe $\mathrm{e}^{21} \mathrm{u}$ ostente ${ }^{22}$ el cargo de facto ${ }^{23} \mathrm{o}$ de iure, se exigirá que la conducta ${ }^{24}$ sea de realización de actuaciones ${ }^{25}$ (por acción u omisión) para que se incumpla la obligación tributaria, de consentimiento (por acción u omisión anterior) del incumplimien-

dos. Zabala Rodríguez-Fornós, A.: Responsables tributarios subsidiarios, en la obra colectiva Comentarios a la Ley General Tributaria (Vols. I y II), BIB $2008 \backslash 943$ y $2008 \backslash 3836$.

${ }^{21}$ No cabe exigir responsabilidad al administrador que ya ha cesado en su cargo, aunque dicha circunstancia no haya sido inscrita (previa destrucción de la presunción registral iuris tantum). En este sentido, puede citarse la STS de 10 mayo 1999 y la STSJ de Murcia de 24 enero 2001 e, incluso, la resolución del TEAC de 8 febrero 2001.

${ }^{22}$ La STS de 14 junio 1993 señala que «la inscripción no tiene carácter constitutivo o de validez del nombramiento de los administradores sociales», conclusión ratificada, a juicio del Tribunal, «al distinguirse dos momentos en el nombramiento: el de su aceptación y posterior presentación en el Registro, pero especificándose que aquél surtirá efectos desde la aceptación». Por tanto, puede afirmarse que el nombramiento de administrador despliega toda su eficacia a partir del momento de la aceptación y no en el de su inscripción.

${ }^{23}$ Lo que resultará más difícil de demostrar en casos de personas jurídicas, pues en los estatutos siempre vendrá reflejado el cargo de administrador de derecho.

${ }^{24}$ Conforme al artículo 236 del Real Decreto Legislativo 1/2010, de 2 de julio, por el que se aprueba el texto refundido de la Ley de Sociedades de Capital (TRLSC), cuando trata los presupuestos y extensión subjetiva de la responsabilidad, norma que: 1. Los administradores responderán frente a la sociedad, frente a los socios y frente a los acreedores sociales, del daño que causen por actos u omisiones contrarios a la ley o a los estatutos o por los realizados incumpliendo los deberes inherentes al desempeño del cargo, siempre y cuando haya intervenido dolo o culpa. La culpabilidad se presumirá, salvo prueba en contrario, cuando el acto sea contrario a la ley o a los estatutos sociales. 2. En ningún caso exonerará de responsabilidad la circunstancia de que el acto o acuerdo lesivo haya sido adoptado, autorizado o ratificado por la junta general. 3. La responsabilidad de los administradores se extiende igualmente a los administradores de hecho. A tal fin, tendrá la consideración de administrador de hecho tanto la persona que en la realidad del tráfico desempeñe sin título, con un título nulo o extinguido, o con otro título, las funciones propias de administrador, como, en su caso, aquélla bajo cuyas instrucciones actúen los administradores de la sociedad.

${ }^{25}$ Por otro lado, la responsabilidad por infracción, que permite a la Administración asegurar en la persona de los administradores la efectividad de las sanciones tributarias. Puede exigírsela a éstos en base a que su comportamiento puede ser el origen de una infracción imputable a la persona jurídica. Las sanciones sólo serán objeto de garantía en tanto que el administrador haya participado en la comisión de la infracción. MARTÍNEZ MICÓ, J. G.: El alcance de la responsabilidad...op. cit.; Permite explicar la traslación de sanciones imputables a la persona jurídica a los administradores, sin violentar el principio de la personalidad de la pena o sanción. También permite la aplicación de los principios y preceptos que configuran el régimen sancionador tributario. Con esta actuación se asegura el cobro de la deuda tributaria y, al mismo tiempo, el de la sanción por la infracción, exigiéndosela, aunque en segundo término, al posible causante. FERNANDO AMOR, J. A.: La responsabilidad fiscal de los administradores y sucesores de personas jurídicas, Bosch, Barcelona, 2005, pág. 58. 
to por sus dependientes ${ }^{26}$ (culpa in vigilando ${ }^{27}$ ) o por adoptar $^{28}$ (por acción favorable) acuerdos ${ }^{29}$ que 'posibiliten ${ }^{30}$ ' esa infracción tributaria $-y$ no otra que nada tenga que ver-. Este precepto guardaría una

${ }^{26}$ La determinación del grado de culpabilidad dependerá esencialmente del volumen y complejidad de la gestión tributaria y del carácter más o menos patente de las irregularidades cometidas. Desde luego, la responsabilidad resultará inexistente cuando conste que los administradores han sido engañados con medios cuyo descubrimiento hubiera exigido una diligencia extraordinaria, o cuando las infracciones sean de tal naturaleza que su descubrimiento por los administradores hubiera exigido una labor de supervisión desproporcionada. Herrera Molina, P. M. La responsabilidad de los administradores en la participación de ilícitos tributarios, Técnica Tributaria, núm. 57, 2002, pág. 92.

${ }^{27}$ ALVAREZ MARTINEZ, J.: LLas responsabilidades tributarias del artículo 40 LGT. Examen de los diferentes supuestos y crítica de la normativa vigente», Impuestos, 1996, Vol. I., pág. 179.

${ }^{28}$ Artículo 237 TRLSC. Carácter solidario de la responsabilidad. Todos los miembros del órgano de administración que hubiera adoptado el acuerdo o realizado el acto lesivo responderán solidariamente, salvo los que prueben que, no habiendo intervenido en su adopción y ejecución, desconocían su existencia o, conociéndola, hicieron todo lo conveniente para evitar el daño o, al menos, se opusieron expresamente a aquél. Artículo 241 bis TRLSC. Prescripción de las acciones de responsabilidad. La acción de responsabilidad contra los administradores, sea social o individual, prescribirá a los cuatro años a contar desde el día en que hubiera podido ejercitarse.

${ }^{29}$ Provenga dicho acto de un órgano colegiado o no; Para González Ortiz si bien el propio acuerdo no infringe directamente el ordenamiento jurídico, lo hace, en cambio, activamente a través de la actuación de un tercero, teniendo las infracciones tributarias su causa en él, de modo que, el acuerdo adoptado y la infracción cometida se encuentran en una relación de causa y efecto. Debe tratarse, bien de instrucciones dadas a otras personas para que actúen de modo determinado, o que sirvan para preparar la adopción de un acuerdo social por un órgano distinto de la persona jurídica. GONZÁLEZ ORTIZ, D.: La figura del responsable en el derecho español, Tesis doctoral dirigida por Cervera Torrejón, F. J., Universitat de València, 2004, pág.251. Así para Morillo Méndez, y desde nuestro punto de vista, se trata de actos preparatorios, pero causalmente necesarios para la comisión de la infracción. MORILLO MÉNDEZ, A.: «Responsabilidades solidarias y subsidiarias después de la Ley 10/1985 de modificación parcial de la Ley General Tributaria», C. T., núm. 53, 1985, pág. 232; En contra, algún autor considera que el precepto se refiere a una declaración de voluntad que posibilite de forma expresa y manifiesta la infracción. PALAO TABOADA, C.: «Responsabilidad tributaria. Los administradores de las sociedades», Impuestos, 1990, Vol. II, pág. 475; difícilmente, puede darse en aquellas sociedades con órgano unipersonal de administración, En todo caso, se exige que exista un nexo causal entre el acuerdo y la realización de la infracción tributaria. Es decir, es necesario que la decisión adoptada conduzca a la comisión del ilícito tributario. Martín Fernández, J.: La responsabilidad de los administradores en la nueva Ley General Tributaria. Conferencia 23 noviembre 2004. Facultad de Derecho de la UCM, Madrid, pág.74; Entienden que los acuerdos deben ser adoptados por órganos colegiados, Merino jara, I.: A MERINO JARA, I.: Acerca de la responsabilidad tributaria, Univ. Extremadura, Anuario de la Facultad de Derecho, núm. 24, 2006, pág. 28 y Navarro Faure, A.: La responsabilidad tributaria de los administradores de empresas, Técnica Tributaria, núm. 52, 2001, pág. 91; Por el contrario, opinan que pueden también ser adoptados por persona o personas que tengan facultad de gestión en la sociedad -a excepción de los que salven su voto, voten en contra, o no asistan- Álvarez Martínez, J.: Álvarez Martínez, $\mathrm{J}$ : La responsabilidad de los administradores de las personas jurídicas en la nueva Ley General Tributaria, Thomson-Aranzadi, Pamplona, 2012, pág. 91 y Lete Achirica, C.: La responsabilidad tributaria de los administradores de sociedades mercantiles, Civitas, Madrid, 2002, pág. 150.

${ }^{30}$ Entendemos que dicha posibilidad debe de resultar verdaderamente creíble y directamente dirigida a la producción del incumplimiento, y que este se produzca -no valdría 
cierta relación de especialidad ${ }^{31}$ con el supuesto del art. 42.1.a) LGT $^{32}$, aunque en el caso del art. 43.1.a) LGT, resultaría privilegiado ${ }^{33}$ el causante o colaborador -el administrador ${ }^{34}$ - que lo sería en la infracción

que la infracción quedara en mera tentativa, salvo que el tipo infractor fuera consumado en grado de tentativa-.

${ }^{31}$ Aunque nuestro punto de vista adopta la tesis de la participación en la infracción tributaria cometida por la persona jurídica, otros autores (por todos DE PALMA), entienden que la responsabilidad subsidiaria lo es por el incumplimiento de la obligación legal de prevenir la infracción cometida por otro, a modo de doble infracción -y ex art. 130.3 LRPAC-, una para la persona jurídica autora, y otra por la autoría (a modo de cooperación necesaria de la infracción principal) como infractor de una obligación legal de prevenir la infracción principal, evitando que otro realice una conducta tipificada como infracción. No se exige responsabilidad subsidiaria al garante por la infracción cometida por la persona jurídica autora material, a quien debía vigilar, sino por su propia participación en los hechos, ya que la infracción ha sido posible porque él (de modo doloso o negligente) ha incumplido la obligación legal de prevenirla, su conducta omisiva le hace cooperador necesario. DE PALMA DEL TESO, A.: El principio de culpabilidad en el Derecho administrativo sancionador, Tecnos, Madrid, 1996, págs. 104-106. Aunque oponemos que estos autores entienden necesario que las personas jurídicas pueden cometer por sí mismas infracciones tributarias, lo que nosotros no compartimos, pues las personificaciones jurídicas son mera ficción de la mediata actuación de sus administradores e inmediata infracción de la persona jurídica, a más que los administradores no previenen sino que cumplen los deberes y obligaciones que les exige la normativa.

32 Bajo la vigencia de la LGT/1963 no cabe duda, a nuestro juicio, que las relaciones entre los arts. 38.1 -responsabilidad solidaria por colaboración en infracciones tributarias- y 40.1 -responsabilidad subsidiaria de los administradores- eran de exclusión. Dicho con otras palabras, la posición de los administradores que colaboran en la realización de un ilícito por parte de la persona jurídica era privilegiada, ya que siempre debía reconducirse a un supuesto de responsabilidad subsidiaria... En la actualidad, sin embargo, la situación ha cambiado... a nuestro juicio, ... si concurren los requisitos para aplicar el art. 42.1.a (LGT 2003) será esta norma la que determine la responsabilidad del administrador. Por tanto, es posible que ésta tenga carácter solidario siempre que pueda afirmarse que la conducta del administrador constituye una colaboración activa en el ilícito. Martín Fernández, J.: La responsabilidad... op . cit. pág.74; La expresión «activamente» contenida en el art. 42.1.a) LGT puede contribuir a diferenciar ambos supuestos. NAVARRO EGEA, M.: El responsable tributario, Iustel, Madrid, 2006, págs. 80-81.

${ }_{33}^{3}$ Pues únicamente en caso de su insolvencia respondería el responsable subsidiario.

${ }^{34}$ Sobre el administrador de hecho, diversas posiciones jurídicas que, obedeciendo siempre a un mismo fundamento el dominio real de la actuación social unido a la concurrencia de alguna irregularidad jurídica en su nombramiento o actuación en realidad dan razón de situaciones que pueden ser bien dispares y comportar efectos contradictorios entre sí. Las diferentes modalidades de administrador de hecho que se presentan en la realidad se pueden agrupar en dos grandes tipologías caracterizadas por una visualización hacia el exterior contradictoria. La panoplia más variopinta de situaciones de administradores de hecho es la que engloba todos aquellos supuestos de administradores aparentes, que se muestran como tales ante terceros formal o materialmente- sin que en realidad concurran en ellos todos y cada uno de los requisitos que la normativa exige del administrador. La segunda figura de administrador de hecho es la que se ubica en el polo opuesto, 
de un tercero ${ }^{35}$, la persona jurídica administrada, ya que difícil resultará encontrar un supuesto de infracción imputable a una sociedad en la que los administradores no hayan intervenido a título de partí-

el administrador encubierto, quien no figurando ante terceros como administrador es quien de forma efectiva administra la entidad. En el marco del administrador aparente cabe, a su vez, distinguir distintos supuestos: a) En un primer sentido se englobarán todos los casos de administradores en cuyo título jurídico se aprecia alguna irregularidad: puede tratarse de la nulidad del nombramiento, por tratarse de un menor o por un defecto formal no susceptible de subsanación en el procedimiento o en el acto por el que se adoptó el acuerdo; es el caso, también, del nombramiento caducado, cuando no se ha inscrito el cese o, sencillamente, se ha abandonado el cargo sin actuar con la diligencia debida para regularizar la situación gerencial de la entidad; y es, por último, el supuesto del nombramiento válido no inscrito en el que, propiamente, no se trata de un administrador de hecho sino de Derecho, desde el momento en que la inscripción tiene mero carácter declarativo, que no constitutivo y que siendo el hecho base de una presunción de administración, ni la por sí misma la prueba de forma irrefutable, ni es imprescindible para que concurra. b) Otra variedad de administrador de hecho de este tipo es el del gestor con poder de decisión, que aparece como tal ante terceros sin que formalmente tenga atribuida la condición de administrador, y que no teniendo por qué ser calificado automáticamente como tal, por su mera condición gerencial- es perfectamente identificable como administrador ficticio. c) Una última forma en la que se puede presentar el administrador de hecho aparente es en los casos de sociedades vinculadas cuando una de ellas ejerce el dominio real sobre otra u otras del grupo, tomándose por la matriz o dominante las decisiones directivas propias del administrador. En cuanto al administrador encubierto es en el en quien concurre la condición más genuina de administración de hecho como opuesta a la administración de Derecho, desde el momento en que su singularidad reside, precisamente, en no presentarse formalmente como tal ante terceros. Es en el administrador de hecho en el que existe una verdadera contraposición entre la administración formal de la sociedad y el dominio real de su actuación efectiva, por cuanto existe una voluntad de ocultación. En su caso el principal problema que presentar la acción derivativa de la responsabilidad ser, justamente, la de la prueba -que en buena medida será frecuente que discurra por indicios y presunciones- de esta disociación entre la apariencia formal y la realidad material que aquella encubre. Rozas Valdés, J. A.: La responsabilidad ...op. cit. págs. 17-18.

${ }^{35}$ A favor PEREZ ROYO, F.: Los delitos y las infracciones en materia tributaria, Madrid, I. E. F., 1986, pág. 297; En contra, HERRERA MOLINA, P.: «Coautoría y participación en las infracciones tributarias y responsabilidad tributaria por actos ilícitos», en la obra Sujetos pasivos y responsables tributarios, Marcial Pons, Madrid, 1997, págs. 704, 708-709, para quien la responsabilidad tributaria prevista en el artículo 38.1 de la LGT, que no se extenderá a las sanciones tributarias impuestas al deudor principal, surgirá: en primer lugar, «cuando la infracción principal haya sido causada mediante una infracción instrumental del responsable tipificada autónomamente»; en segundo lugar, «en las hipótesis de mera complicidad (en el sentido del Código Penal); y, dudosamente, "en el caso de una colaboración puramente material en la infracción»; Matizadamente algún autor expresa que mientras el art. 42.1.a) LGT exige la participación directa y material del administrador, no así lo hace el art. 43.1.a) LGT. ATAZ HERNANDEZ, J.: «La responsabilidad de los administradores de sociedades en materia fiscal», en Estudios de Derecho Fiscal. Homenaje a Jaime Basanta, Madrid, AEB-Civitas, 1994. págs. $75-76$. 
cipes $^{36}$ o autores, por lo que en este supuesto se trata de una sanción tributaria o técnica sancionatoria encubierta, a la que le resultará de aplicación los principios del ejercicio de dicha potestad. En cualquier caso, entendemos, en aras a garantizar el principio de culpabilidad y proporcionalidad ${ }^{37}$, que debería probarse que si el administrador hubiera cumplido con los mencionados deberes, la infracción tributaria no se habría producido ${ }^{38}$. En cualquier caso, no parece lógico que se permita, por una fictio iuris del derecho, ser sujeto infractor por las

${ }^{36}$ Ejemplos de definición de diligencia de un empresario los encontramos en los artículos 4 de la Ley 3/1991, de 10 de enero, de Competencia Desleal, «[e]n las relaciones con consumidores y usuarios se entenderá contrario a las exigencias de la buena fe el comportamiento de un empresario o profesional contrario a la diligencia profesional, entendida ésta como el nivel de competencia y cuidados especiales que cabe esperar de un empresario conforme a las prácticas honestas del mercado, que distorsione o pueda distorsionar de manera significativa el comportamiento económico del consumidor medio o del miembro medio del grupo destinatario de la práctica, si se trata de una práctica comercial dirigida a un grupo concreto de consumidores. A los efectos de esta ley se entiende por comportamiento económico del consumidor o usuario...»; arts.159.4.b), 162.2.c) y d) del Real Decreto Legislativo $1 / 2007$, de 16 de noviembre, por el que se aprueba el texto refundido de la Ley General para la Defensa de los Consumidores y Usuarios y otras leyes complementarias; arts. 68.1, 350, RDLg 1/2010 (TRLSC); el art. 225 RDLg. 1/2010. Deber general de diligencia. 1. Los administradores deberán desempeñar el cargo y cumplir los deberes impuestos por las leyes y los estatutos con la diligencia de un ordenado empresario, teniendo en cuenta la naturaleza del cargo y las funciones atribuidas a cada uno de ellos. 2. Los administradores deberán tener la dedicación adecuada y adoptarán las medidas precisas para la buena dirección y el control de la sociedad. 3. En el desempeño de sus funciones, el administrador tiene el deber de exigir y el derecho de recabar de la sociedad la información adecuada y necesaria que le sirva para el cumplimiento de sus obligaciones; Artículo 226 (TRLSC). Protección de la discrecionalidad empresarial. 1. En el ámbito de las decisiones estratégicas y de negocio, sujetas a la discrecionalidad empresarial, el estándar de diligencia de un ordenado empresario se entenderá cumplido cuando el administrador haya actuado de buena fe, sin interés personal en el asunto objeto de decisión, con información suficiente y con arreglo a un procedimiento de decisión adecuado. 2. No se entenderán incluidas dentro del ámbito de discrecionalidad empresarial aquellas decisiones que afecten personalmente a otros administradores y personas vinculadas y, en particular, aquellas que tengan por objeto autorizar las operaciones previstas en el artículo 230; art. 14 de la Ley 12/1991, de 29 de abril, de Agrupaciones de Interés Económico; arts. 40.4, 62.1 de la Ley 35/2003, de 4 de noviembre, de Instituciones de Inversión Colectiva; arts. 37.3, 59.1.b), 62.4.a), de la Ley 22/2014, de 12 de noviembre, por la que se regulan las entidades de capital-riesgo, otras entidades de inversión colectiva de tipo cerrado y las sociedades gestoras de entidades de inversión colectiva de tipo cerrado, y por la que se modifica la Ley 35/2003, de 4 de noviembre, de Instituciones de Inversión Colectiva; art. 9.2.a) de la Ley 12/1992, de 27 de mayo, sobre Contrato de Agencia; arts. 35.1, 36, de la Ley 22/2003, de 9 de junio, Concursal.

${ }^{37}$ Obligar a pagar la sanción ajena, aunque en determinados casos no sea contrario al principio de personalidad de la pena, sí se opondrá al principio de proporcionalidad.

${ }^{38}$ Exigiendo colaboración en la infracción y culpabilidad, Álvarez Martínez, J.: La responsabilidad... op. cit., págs. 75- 76. 
acciones realizadas directamente por sus administradores, para a reglón seguido hacer a estos responsables del pago de la sanción tributaria cometida ${ }^{39}$.

La condición de administrador ${ }^{40}$ no depende de la denominación ${ }^{41}$ que se dé a la persona o cargo, sino del efectivo contenido legal o estatutario de sus cometidos, según éstos confieran atribuciones conformadoras de la voluntad social y en definitiva integradas en ella, o sólo supongan una representación, en la que los actos del sujeto aparecen diferenciados de dicha voluntad social, aunque sean imputables a la entidad a título de representado ${ }^{42}$. El administrador será quien -por sí

${ }^{39}$ Esta situación nos lleva a concluir que el legislador para luchar eficazmente contra las infracciones cometidas en el curso de la actuación de una persona jurídica, debería complementar la responsabilidad directa de las personas físicas que han realizado la acción típica con otras medidas no propiamente sancionadoras impuestas a la persona jurídica, pero no sancionar a la persona jurídica para, seguidamente, convertir en responsable subsidiario al autor real de los hechos antijurídicos.

${ }^{40} \mathrm{Si}$ bien es cierto que en muchos casos los administradores, al levantar el velo, no son más que las manos y los pies de las sociedades mercantiles, también es cierto que habrá ocasiones en las que los administradores no tengan nada que ver con las decisiones de la sociedad de incumplir las obligaciones tributarias, que vendrán impuestas por los socios o partícipes que pretendan el cese de actividades. Álvarez Arroyo, F.: Derivación de responsabilidad a los administradores de sociedades, Jurisprudencia Tributaria Aranzadi paraf.núm.3012/2002, BIB $2002 \backslash 1674$.

${ }^{41}$ En este mismo sentido se han pronunciado igualmente GALIANO ESTEBAN e IZQUIERDO RIVAS, quienes han escrito que: «el concepto de administrador no depende tanto del nombre que se le dé al cargo sino del contenido de sus funciones legal y estatutariamente previstas, de su nombramiento por la Junta General y de su status como órgano social con sus propias normas de nombramiento, capacidad, aceptación, inscripción y cese en el cargo». En otras ocasiones, por el contrario, se ha sustentado la tesis opuesta, habiendo afirmado, por ejemplo, MARTÍN FERNÁNDEZ que al no definir la norma tributaria lo que debe entenderse por administrador, hay que acudir necesariamente a las normas especiales que regulan la materia, y, en concreto, a las que establece el régimen jurídico de las sociedades mercantiles, anónimas o de responsabilidad limitada, de las que se desprende que el concepto de administrador no viene delimitado por el contenido y alcance de las funciones a desempeñar, no siendo, pues, tal, ni siquiera a efectos fiscales, la persona que ejerza de forma efectiva la gestión y lleve la dirección económica de la entidad de que se trate. En este sentido véanse, entre otras, las Resoluciones del TEAC de 18 noviembre 1999, 11 febrero 2000, 7 junio 2000 y 26 abril 2001. CHECA GONZÁLEZ, C.: Notas sobre la nueva regulación...op. cit.

${ }^{42}$ Con anterioridad al TRLSC se expresaba que: la representación supone la existencia de dos voluntades diferenciadas, la del apoderado y la del poderdante, ambas dotadas de autonomía en tanto que los administradores son, en principio, un órgano social -no necesariamente miembro o socio- integrado en la estructura de la personalidad jurídica colectiva, que actúa a través de ellos. Los consejeros delegados, designados en el ámbito del órgano de administración para realizar facul- 
solo, en unión de otros administradores, o integrado colegiada y solidariamente en el Consejo de Administración- gestiona la persona jurídica con autonomía decisoria, realizando actos decisivos para la actividad social, de dirección o disposición, que rebasan la mera administración. La responsabilidad de los administradores [de sociedades y de cualquier tipo de entes colectivos con personalidad jurídica, entre los que no cabe entender incluidos los entes del art. 35.4 $\mathrm{LGT}^{43}$ ] exige la determinación, como cuestión previa, de a quiénes debe atribuirse esta condición, teniendo en cuenta, de una parte, que los administradores pueden ser confundidos con los representantes -incluso por las normas positivas- o con los meros colaboradores en la gestión de la empresa, vinculados a ella por relaciones laborales o de servicios, siendo así que frecuentemente aparecen en los entes sociales una serie de órganos o personas cuya posición no siempre es nítida, y por otra parte, que la administración efectiva de una persona colectiva podía detentarse por quienes no aparecían formalmente como administradores, sino por otros sujetos que, incluso, podían no ser socios y actuar por persona interpuesta. Lo que, por cuestiones de sistemática, podemos clasificar los administradores de hecho, que pueden ser personas físicas o jurídicas, en dos tipos, así el llamado administrador «de hecho», como noción negativa o contrafigura del de derecho, que se produce en un amplio espectro de situaciones reconducibles a dos grandes tipos: a) el del administrador de hecho aparen-

tades de gestión ordinaria o cotidiana de la sociedad, ven limitada su función en aspectos decisivos, aproximando su condición a la propia de un representante o apoderado más o menos general, de modo que la delegación de facultades no exonera de responsabilidad a los delegantes de los actos de los delegados, al menos por su deber in vigilando -sin que ello excluya una responsabilidad específica de estos últimos por incumplimiento o exceso en las facultades delegadas-; no obstante, los consejeros delegados serían administradores si tal condición apareciera unida al cargo o al contenido de la función de administrador ( ex art. 141.1 LSA). El Director-gerente o Director-general será administrador en cuanto comparta su actividad con el Consejo de Administración o ejerza funciones de tal, lo que sucederá usualmente -en particular cuando sea designado estatutariamente-, sin descartar la posibilidad de que como órgano social su condición sea asimilable a la de un apoderado general o factor. El Secretario del Consejo no será administrador, a menos que ostente la condición de tal, sin perjuicio de la responsabilidad en que pueda incurrir por incumplimiento de sus obligaciones legales (así, arts. 110 y 142 LSA). ZABALA RODRÍGUEZ-FORNÓS, A.: Comentarios a los artículos 35 a 48 de la LGT, en HERRERO DE EGAÑA Y ESPINOSA DE LOS MONTEROS, J. M. (coord.), Comentarios a la Ley General Tributaria, Volumen I, Aranzadi, Navarra, 2008, págs. 368-ss.

${ }^{43}$ Los entes del art. 35.4 LGT, que carecen de personalidad jurídica aun cuando se les atribuye subjetividad tributaria, dado que dichos entes siguen un régimen jurídico propio de «representación» o administración del conjunto patrimonial. Ibid. op . cit. págs. 368-ss. 
te o notorio ${ }^{44}$, surgido de irregularidades en la atribución o mantenimiento del cargo, cuyo tratamiento jurídico responde al reconocimiento jurídico de la realidad resultante de la apariencia, por razones obvias de seguridad jurídica, y se dirige básicamente a garantizar la continuidad de la empresa; b) el del administrador de hecho encubierto $u$ oculto ${ }^{45}$, que resulta de una finalidad de mantener indeterminada o encubierta la condición de administrador para eludir la responsabilidad que ésta entraña, con lo que su consideración jurídica atiende dominantemente a evitar o impedir esta elusión.

Únicamente podrá responsabilizarse del pago de sanciones tributarias al administrador o administradores de hecho por ausencia o imposible determinación de los de derecho, o cuando se acredite que éstos constituyen mera interposición ficticia, sin que se exija, sin em-

${ }^{44}$ Son administradores de hecho aparentes o notorios quienes, sin título jurídico formalmente válido y eficaz, se comportan manifiestamente en el tráfico como administradores, ante los socios o ante terceros, al menos por consentimiento o tolerancia de éstos y asunción por la entidad de los resultados de su gestión (STS 24 septiembre 2001). Puede tratarse de administradores con cargo caducado, decaídos, en situación de prórroga o de reelección o aceptación de hecho; situaciones que, en general, no impiden que la jurisprudencia reconozca la validez de sus actos, mediante interpretaciones de las normas basadas en las ideas de subsistencia interina del cargo o de continuidad de la empresa. Cabrá, pues, diferenciar los casos que tales administradores pueden ser considerados de derecho -así, por prórroga o continuidad legal en el cargo de aquellos que lo son estrictamente de hecho-. Así, atendiendo al carácter no constitutivo de la inscripción registral del nombramiento, que surte efectos desde su aceptación, la posibilidad de aceptación implícita o tácita por ejercicio de las funciones, la existencia de vínculos contractuales con la entidad o de gestión de negocios ajenos; también al incumplimiento de requisitos de forma o quebrantamiento de obligaciones o deberes en la renuncia, a la caducidad no automática del cargo (art. 145.1 RRM), etc. (p.ej. RsDGRN 13 mayo 1998, y 4 junio 1998).

${ }^{45}$ Los administradores de hecho encubiertos son frecuentes en los casos de sociedades unipersonales, familiares, de socio mayoritario o "dueño» de la empresa ( SsTS 23 marzo 1998, 10 julio 1998), pero también pueden ser ocultos bajo apariencias de director-gerente o apoderados generales, o administradores en la sombra, que actúan por inducción en la conducta de otros. Un Director General puede ser asimilado al administrador de hecho en razón de la amplitud de sus poderes, máxime si comprenden facultades indelegables o si el cargo de administrador se ocupa por persona insolvente ( SsTS 23 marzo 1998, 26 mayo 1998, 7 junio 1999). Estos casos exigen calificar o «recalificar» su condición, usualmente mediante prueba de presunciones e indicios -actos, vínculos personales, administradores legales que son socios minoritarios, no socios o personas insolventes, relaciones de dominio entre una entidad y otra dominada-, sin que ello precise necesariamente la inexistencia de administrador designado, pues bastará establecer la relación de éste con quien ejerza efectivamente o de hecho la administración, habida cuenta que, como determinadas funciones o actos no pueden ser formalmente realizados por un administrador de hecho, el de derecho puede actuar como "pantalla» o instrumento de aquél. 
bargo, que los procedimientos de declaración de responsabilidad sean independientes para cada uno o cada clase de ellos, ni expedientes sucesivos. Nada obstará a la tramitación de un solo expediente dirigido contra quienes sean realmente administradores, una vez descartados los aparentes por existir razonables indicios para ello, ni tampoco que el fracaso de la actuación administrativa contra el administrador aparente, impida incoar otro u otros procedimientos declarativos de responsabilidad mientras no haya prescrito la acción ${ }^{46}$.

En resumen, el apartado a) del art. 43.1 impone la responsabilidad en el pago de la sanción tributaria de las personas jurídicas, que hubieran cometido infracciones tributarias, a los administradores de hecho ${ }^{47}$ o de derecho ${ }^{48}$ de éstas que «no hubiesen realizado ${ }^{49}$ los actos necesarios que sean de su incumbencia ${ }^{50}$, para el cumplimiento de

${ }^{46}$ Ibid. op. cit.

${ }^{47}$ Según la doctrina y la jurisprudencia sobre este particular, podrá declarase responsable a aquella persona que ejercite las funciones típicas del administrador, esto es, quien efectúe la dirección y gestión de una entidad jurídica, independientemente de la existencia de un nombramiento formal al efecto. La condición de administrador podrá demostrase a través de indicios tales como ser accionista mayoritario, ostentar funciones de apoderado general con amplias facultades, la importancia de la remuneración percibida, el trato personal constante con proveedores y clientes o la relación inmediata con el personal de la sociedad DÍAZ ECHEGARAY, J. L.: El administrador de hecho de las sociedades, Aranzadi, Navarra, 2002, págs. 143 y 190 y ss; ÁLVAREZ MARTÍNEZ, J.: La responsabilidad ...op. cit., pág. 73; SsAP de la Coruña (Sección 4. a) de 17 de enero de 2000 y 26 de junio de 2009 y de La Rioja (Sección 1.a) de 27 de diciembre de 2010.

${ }^{48}$ Sólo se consideran administradores de estas entidades las personas a que hacen referencia tales normas y con independencia de la denominación que figure en los estatutos sociales. Para la STSJ de Murcia de 26 junio 1996, en «el término «Administrador» hay que entender incluido a todo aquél que actúe como órgano de administración de la sociedad anónima, sea unipersonal o pluripersonal». Si la Ley hubiera querido referirse a otro tipo de personas -gerentes, apoderados, etc.- hubiera utilizado un término diverso o los hubiera mencionado expresamente. Martín Fernández, J.: La responsabilidad ...op. cit., pág. 69.

${ }^{49}$ En efecto, en el artículo 43.1(a) de la LGT son tanto las conductas activas, como adoptar acuerdos, como conductas pasivas, que no hubiesen realizado actos de su incumbencia para el cumplimiento de las obligaciones tributarias o hubiesen consentido el incumplimiento por quienes de ellos dependen. La cuestión es si todas estas conductas pueden ser cometidas por los administradores de hecho. Parece pacato afirmar que las conductas activas sí. Ahora bien, y al margen de la muy difícil cuestión de la prueba, las conductas activas creemos que habría que ubicarlas dentro del artículo 42.1(a) como un supuesto responsabilidad solidaria por causar o colaborar de forma activa. De esta manera, los administradores de hecho serían responsables solidarios y los formales sólo podrían ser subsidiarios. BLÁZQUEZ LIDOY, A.: La responsabilidad tributaria del administrador de hecho en la LGT/2003 (y II): elementos del régimen de responsabilidad, Jurisprudencia Tributaria, Aranzadi núm.2/2005, BIB 2005\911.

${ }^{50}$ La relación del administrador con el ilícito supone algo más que la culpa genérica, exige en la omisión que se trate de actos que fuesen de su incumbencia 
las obligaciones y deberes tributarios o hubiesen consentido (por omisión del deber de vigilar) ${ }^{51}$ el incumplimiento por quienes de

y para los que tuviera encomendada la función de realizarlos, superando (en caso de incumplimiento de las obligaciones por las personas que de ellos dependan) el mero supuesto de subordinación o dependencia orgánica entre el administrador y el causante del incumplimiento. Quiero decir que, salvo supuestos concretos como el de Administrador Único, habrá que atender a la concreta división de funciones de la entidad jurídica para detectar la persona física que tenga determinados poderes de dirección o deberes de vigilancia. Martínez Alonso, J. I.: La responsabilidad...op. cit. pág. 48; No cabrá derivar la responsabilidad al administrador que hubiera cesado en el cargo en el instante en que se efectuaron los actos constitutivos de la misma, aunque no conste inscrito tal cese en el Registro Mercantil. GARCÍA NOVOA, C.: Notas sobre la responsabilidad tributaria del Administrador de hecho, en VILLAR EZCURRA, M. (dir.), Estudios jurídicos en memoria de Don César Albiñana García-Quintana, Vol. I, IEF-Ministerio de Economía y Hacienda, Madrid, 2008, págs. 664-ss.; ZABALA RODRÍGUEZ-FORNÓS, A.: Comentarios...op. cit. págs. 368-ss; ÁLVAREZ MARTÍNEZ, J.: La responsabilidad ... op. cit., pág. 66 .

${ }^{51}$ No se trata de la mera omisión de una obligación in vigilando, sino de una actitud de tolerancia ante dicho incumplimiento, que no necesariamente reside en el del resultado la infracción, bastando simplemente que lo posibilite, lo que incluirá no impedirlo, corregirlo o subsanarlo por acción u omisión. ZABALA RODRÍGUEZ-FORNÓS, A.: Comentarios...op. cit. págs. 368-ss; Por nuestra parte, pensamos que la obligación, por su carácter «necesario» debe querer tratar de imputar responsabilidad in vigilando, y no meras faltas por culpa leve o grave, pero nunca por dolo; El verdadero nudo gordiano estará en las conductas pasivas y sobre todo en si es posible hablar de un deber de diligencia en los administradores de hecho y en si tienen culpa in vigilando. Hay que tener en consideración que la jurisprudencia tributaria acude para justificar la responsabilidad tributaria a un concepto mercantil del deber in vigilando, concepto que hasta la reforma de la Ley 26/2003 operaba sólo para los administradores formales. A mi parecer, sin embargo, con relación al deber de diligencia es necesario distinguir entre los distintos tipos de administradores de hecho. La culpa in vigilando, como ha señalado la doctrina mercantil, sería atribuible a los administradores con cargo caducado, o con nombramiento viciado, y también a los administradores notorios o que se presentan como tales ante terceros (siempre y cuando tengan capacidad de gestión efectiva). El verdadero problema estará en los administradores ocultos o en la sombra y los directores generales y apoderados. Con relación a estos últimos, directores y apoderados, nos parece claro que en ningún caso estarán sometidos a responsabilidad cuando sean trabajadores de la sociedad y exista realmente una relación jerárquica con los administradores, pues mercantilmente esta posibilidad es, a día de hoy, inviable. El administrador real tiene un deber de control sobre los directores generales, con independencia de que en la vida empresarial ni se lleve a cabo o, incluso, ni se tengan conocimientos para hacerlo. El problema estará cuando el director general sea, a su vez, el accionista mayoritario de la entidad y el administrador formal una figura sin poder. En ese caso, entendemos que sí es exigible el deber de diligencia y la culpa in vigilando en tanto son administradores y se les debe exigir el mismo comportamiento que a los de derecho. Con relación a los administradores ocultos, cuando los administradores formales operan con autonomía y aquéllos se limitan a impartir las directrices generales o específicas (pensemos en socios mayoritarios en grupos de sociedades) creemos que no es posible exigir esa vigilancia, y por tanto, sólo 
ellos dependan o hubiesen adoptado de acuerdos que posibilitasen ${ }^{52}$ las infracciones (siempre que dicha infracción se consume ${ }^{53}$, pues sin infracción no hay sanción tributaria ni objeto de derivación -sin perjuicio de la derivación de la deuda tributaria, que no es objeto de nuestro estudio-)». Se trata de una responsabilidad en el pago de sanciones tributarias ${ }^{54}$ por implicar, al menos, dolo, y no meramente algún tipo de negligencia, antijuridicidad que podría resultar exclui-

responderían por conductas activas. Por tanto, la mayor controversia se encuentra con los administradores ocultos con ejercicio real y efectivo de toda la gestión. A nuestro parecer, si hay el más mínimo resquicio para una administración autónoma del administrador formal no será posible exigirle la responsabilidad in vigilando. Sólo en los casos donde el administrador sea un testaferro cabrá exigirle al administrador de hecho el mismo deber de diligencia que al administrador formal. Blázquez Lidoy, A.: La responsabilidad tributaria del administrador...op. cit.

${ }^{52}$ Dichos acuerdos deben ser de su incumbencia para el cumplimiento de las obligaciones y deberes tributarios de ésta. Se trata de actos pertenecientes al ámbito de las funciones del administrador -legal, estatutariamente o por acuerdo social ya que no se distinguen-y «necesarios» en el sentido de su imperativa observancia por el administrador o precisos en el cumplimiento de deberes u obligaciones de éste. No se trata de que la conducta del administrador produzca directamente la infracción, pues, de otro modo, nos hallaríamos ante una cooperación necesaria o una complicidad en la infracción que haría aplicable la responsabilidad solidaria del art. 42.1.a) LGT. Ibid. op. cit.; Por nuestra parte, indicamos que si el acuerdo posibilita la infracción, dicha posibilidad debe de ser rectamente dirigida a la comisión de la infracción tributaria, y que la infracción se haya consumado, pues en caso de falta de consumación no cabrá derivar una sanción de una infracción que nunca se consumó, pues sólo en algunos tipos la consumación infractora se produce con la mera tentativa idónea (v.gr. art. 194 LGT).

${ }^{53}$ Haber salvado el voto -no la mera abstención en la votación- o no haber asistido a la reunión en que se adoptó aquélla, cuando el acuerdo derive de una decisión colectiva, llevaría a la inaplicación de este presupuesto [ ex art. 179.2.c)], que requiere la "adopción» de acuerdos, a menos que, sin perjuicio de ello, existieran decisiones del administrador que de algún modo posibilitasen la infracción. Zabala Rodríguez-Fornós, A.: Responsables tributarios subsidiarios...op. cit.

${ }^{54}$ Por último, dado que la responsabilidad del administrador deriva de adoptar acuerdos que posibiliten las infracciones de la persona jurídica, no se requiere que éstas se hayan producido. Zabala Rodríguez-Fornós, A.: Responsables tributarios subsidiarios...op. cit. 
da en casos justificados de ausencia ${ }^{55}$ o disidencia ${ }^{56}$ manifiesta del administrador y cuando la conducta de éste respondiera a una inter-

${ }^{55}$ Es obvio que la responsabilidad plasmada en el artículo 43.1 a) del referido texto legal no resultaría exigible a aquellos administradores en quienes concurrieran alguna de los dos siguientes circunstancias: a) no haber asistido a la reunión en que se adoptó el acuerdo causante de la infracción; b) haber asistido a la reunión en cuestión, pero salvando su voto en lo que concierne a dicho acuerdo... la determinación de su concurrencia o no exigirá efectuar un examen específico del caso concreto ante el cual nos encontremos, pudiendo distinguirse, a nuestro juicio, las tres siguientes situaciones: $1 .^{\mathrm{a}}$ Asistencia, en persona, del administrador a la reunión en que se adoptó el acuerdo que generó la infracción tributaria, oponiéndose expresamente al mismo: en este caso, dicha oposición expresa al acuerdo adoptado -la cual deberá quedar necesariamente reflejada, previa solicitud del administrador disidente, en el acta de la sesión correspondiente (arts. 26.1 CCom y 97.1 RRM)- revela, como es obvio, la falta de participación de aquél en el ilícito cometido, no siendo posible, en consecuencia, exigir ningún tipo de responsabilidad al administrador que hubiera procedido en el sentido ahora indicado. 2. ${ }^{\mathrm{a}}$ Asistencia, por representante, del administrador a la reunión en que se adoptó el acuerdo que generó la infracción tributaria: en esta hipótesis de actuación por representante -posibilidad expresamente contemplada y permitida por la normativa mercantil (arts. 139 LSA y 97.1 RRM) - no cabe duda alguna de que será el voto ejercitado por el susodicho representante el que determine si el administrador representado ha asumido o no el acuerdo adoptado, debiendo efectuarse, empero, algunas matizaciones importantes. A este respecto, resulta evidente que la responsabilidad resultará exigible al administrador cuando su representante hubiera votado a favor de dicho acuerdo, ya de una forma voluntaria y libre -esto es, sin sujeción a instrucción alguna-, ya por tener instrucciones expresas de aquél en dicho sentido (art. 1719 CC); frente a ello, no procederá la exigencia de tal responsabilidad cuando el representante hubiera votado en contra del acuerdo, ni tampoco, a nuestro modo de ver, cuando lo hiciere a favor si, en esta concreta hipótesis, el administrador demostrase, de modo concluyente, la existencia de órdenes expresas suyas en sentido contrario y la vulneración de las mismas por parte de aquél. 3 . $^{\mathrm{a}}$ Inasistencia del administrador a la reunión en que se adoptó el acuerdo que generó la infracción tributaria: en este supuesto la exención de responsabilidad se producirá siempre que los administradores ausentes acrediten que la mencionada inasistencia se encontraba justificada y que fue debida a un motivo ajeno a su voluntad -pudiendo ubicarse incluso esta situación en la hipótesis de «fuerza mayor» contemplada en el artículo 179.2 b) de la LGT-. En cambio, en caso de inasistencia libre, voluntaria e injustificada, entendemos -pese al tenor literal de la letra c) del mencionado precepto- que los administradores ausentes deberían quedar sometidos a la correspondiente responsabilidad por infracciones tributarias al haber actuado de una forma negligente en el ejercicio de su cargo, en la medida en que han incumplido una obligación -la relativa a la asistencia a las reuniones- a la que están sujetos en su condición de tales, actitud ésta que, como ya se ha señalado, revestirá una especial gravedad cuando, de haber asistido, su voto hubiera podido ser determinante en aras a evitar la adopción del acuerdo que posibilitó la respectiva infracción. ÁLVAREZ MARTÍNEZ, J.: La exención de responsabilidad en los supuestos de infracciones tributarias derivadas de la adopción de decisiones colectivas: una interpretación correctiva e integradora del artículo 179.2.c) de la LGT, Quincena Fiscal, núm.10/2009, BIB 2009\538.

${ }^{56}$ Quedan excluidos los administradores que «hubieran salvado su voto o no hubieran asistido a la reunión en que se tomó la misma», de conformidad con el art. 179.2.c) de la LGT/2003. Ibid. op. cit. pág. 75. 
pretación razonable de las normas. El precepto trata de separarse ${ }^{57}$ -aunque de modo incorrecto- del supuesto del art. 42.1.a) LGT, cuando expresa «sin perjuicio de lo dispuesto en la letra a) del apartado 1 del artículo $42 »$, es decir, sin perjuicio de que pueda proceder la declaración de responsabilidad solidaria de los causantes o colaboradores en una infracción tributaria, tanto del administrador como de otras personas.

Así, la responsabilidad del art. 42.1.a) LGT será exigible a personas o entidades que no necesariamente sean administradores, como son los socios, agentes o empleados de la entidad, e incluso terceros, al no requerirse que se trate de sujetos integrados o jurídicamente relacionados con la persona jurídica infractor, bastando con que intervengan "causando» o "colaborando» en una infracción de un tercero.- El art.42.1.a) LGT se refiere a una participación directa e inmediata en la infracción, en términos necesarios para que ésta se produzca, entretanto el art. 43.1.a) LGT no exige en el administrador tal grado de participación, aunque sí la misma intencionalidad en la infracción, si bien demanda un doble ${ }^{58}$ incumplimiento de obligacio-

${ }^{57} \mathrm{El}$ presupuesto opera «sin perjuicio de lo dispuesto en la letra a) del apartado 1 del artículo 42», es decir, sin perjuicio de que pueda proceder la declaración de responsabilidad solidaria de los causantes o colaboradores en una infracción tributaria, tanto del administrador como de otras personas. Con lo que se compatibiliza del presente presupuesto de responsabilidad con el establecido por el art. 42.1.a) LGT resolviendo así las dudas antes planteadas, según vimos, por la relación de los arts. 40.1 y 38.1 LGT 1963... Por lo tanto, cuando la conducta del administrador tenga la entidad requerida por el art. 42.1.a), lo procedente será declararlo responsable solidario por aplicación de este precepto, aunque obviamente sin concurrencia de ambos por una misma conducta. ZABALA RODRÍGUEZ-FORNÓS, A.: Comentarios (al artículo 43)... op. cit. págs. 368 -ss.

58 « Se exige en primer lugar la declaración administrativa de la existencia de una infracción tributaria imputada a la persona jurídica, dado que como sujeto pasivo es el responsable principal del incumplimiento tributario »;... En segundo lugar, deben ostentar en el momento de cometerse el ilícito tributario el cargo de administradores, para derivar hacia ellos la responsabilidad;... Y por último, " como tercer requisito, se precisa de una conducta ilícita por parte del administrador »...declarada la comisión de la infracción tributaria por la sociedad, en tanto que obligada principal al pago, como uno de los principales requisitos exigidos en estos supuestos, " queda expedita la vía de derivación de responsabilidad de los administradores que hubiesen actuado con pasividad, con dejación, con negligencia en definitiva en el cumplimiento de sus obligaciones, una vez declarado fallido el deudor principal ", y ojo, " por lo que al responsable subsidiario corresponde acreditar que actuó con la debida diligencia, como le exige el art. 127 LSA « los administradores desempeñarán su cargo con la diligencia de un ordenado empresario y de un representante legal ». Esto significa, por la inversión del principio onus probandi, que es al demandante a quien corresponde acreditar el hecho impeditivo o extintivo de dicha responsabilidad ...O lo que es lo mismo, que una vez haya sido declarada la comisión de una infracción por la sociedad, tras el correspondiente expediente sancionador llevado a 
nes y deberes, por las personas jurídicas y por los administradores que no han realizado actos necesarios para el cumplimiento ${ }^{59}$, lo consientan o lo posibiliten ${ }^{60}$. La responsabilidad de los administradores puede derivar de consentir el incumplimiento de obligaciones tributarias de la persona jurídica por quienes de ellos dependan, esto es, de quienes se encuentran bajo la esfera de gestión y funciones del administrador, incluyendo a los representantes voluntarios de la persona colectiva y a los designados por el propio administrador. No se trata de la mera omisión de una obligación (por culpa) in vigilando, sino de una actitud de permisión (dolosa) ante dicho incumplimiento, que no necesariamente incide en el del resultado la infracción, bastando para

cabo por la Administración, ello supone la inversión de la carga de la prueba respecto del administrador en dicha fecha; el cual ha de ser quien demuestre fehacientemente que sí ha realizado los actos necesarios que son de su incumbencia para el cumplimiento de las obligaciones tributarias infringidas, que no ha consentido el incumplimiento por quienes dependen de él, y que además tampoco ha adoptado acuerdos que hicieran posibles tales infracciones, para de esa forma, impedir que se le considere como responsable subsidiario y se le pueda derivar la exigencia del pago de las cantidades adeudadas por la entidad, si ésta resulta insolvente, extinguiendo su responsabilidad.... Dicho más sencillamente, aquí hay un supuesto de responsabilidad subsidiaria, que tiene el alcance general establecido por los arts. 37.3. ${ }^{\circ}$ LGT y 14-3. ${ }^{\circ}$ RGR, mas un supuesto de responsabilidad en la sanción, que recae a su vez sobre el mismo responsable subsidiario; dado que por el principio de responsabilidad personal o personalidad en la sanción, es considerado también infractor en tanto que partícipe en la comisión del ilícito correspondiente por la sociedad, como cooperador necesario y relevante, en palabras de la Inspección transcritas por el Tribunal. FERNÁNDEZ PAVÉS, M. ${ }^{\mathrm{a} J} .:$ ¿Ahora resulta que todos los administradores de sociedades incumplidoras con Hacienda, son responsables subsidiarios mientras no demuestren lo contrario?, Jurisprudencia Tributaria, Aranzadi paraf. núm.176/2003, BIB 2003\825.

${ }^{59}$ Se trata de actos pertenecientes al ámbito de las funciones del administrador -legal, estatutariamente o por acuerdo social ya que no se distingue- $\mathrm{y}$ «necesarios» en el sentido de su imperativa observancia por el administrador o precisos en el cumplimiento de deberes u obligaciones de éste. No se trata de que la conducta del administrador produzca directamente la infracción, pues, de otro modo, nos hallaríamos ante una cooperación necesaria o una complicidad en la infracción que haría aplicable la responsabilidad solidaria del art. 42.1.a) -requerida por otra parte, aunque con significado impreciso, de una participación «activa»-. Zabala Rodríguez-Fornós, A.: Responsables tributarios subsidiarios...op. cit.

${ }^{60}$ Así la comisión de la infracción por la persona jurídica se presenta como razón del carácter subsidiario de la responsabilidad, que habrá de ser previamente exigida a dicha persona jurídica hasta finalizar con la falencia de ésta tras el correspondiente procedimiento de apremio (art. 182.2 LGT), sin perjuicio de adoptar medidas cautelares. El art. 212.3 LGT, sin embargo, establece la automática suspensión de «la ejecución de las sanciones» en período voluntario y sin necesidad de aportar garantías «hasta que sean firmes en vía administrativa», lo que supone que tampoco se pueda exigir el pago de la sanción al responsable tributario, sin perjuicio de adoptar medidas cautelares que procedan. Zabala Rodríguez Fornós, A.: Comentarios a la Nueva Ley General Tributaria, coord. Huesca Boadilla, R., Thomson-Aranzadi, Pamplona, pág. 327. 
el legislador que simplemente lo posibilite ${ }^{61}$, lo que incluirá no impedirlo, corregirlo o subsanarlo por acción u omisión. De este modo, cuando el tipo legal preceptúa que «las personas jurídicas que, habiendo éstas cometido infracciones tributarias ${ }^{62}$ », no debe llevarnos a entender que los administradores respondan de cualquier tipo de sanciones tributarias ${ }^{63}$, sino que «su responsabilidad también se extenderá al pago de las sanciones» tributarias en las que hubiera participado -participación que será según los supuestos que describe el tipo-, y no a todas las sanciones tributarias, aunque no haya participado de ninguna manera.

Debemos entender que las referencias a los administradores de hecho ${ }^{64}$, únicamente se deben entender hechas, a lo sumo, al supuesto

${ }^{61}$ Con lo que podríamos entrar a barajar supuestos, como se plantea la doctrina penalista, de dolo hipotético o eventual. Según nuestro parecer, el dolo debe ser directo y debe pretender la realización y consumación de la infracción y dicha infracción debe haberse producido -aunque se trate de una infracción cuya consumación exija meramente la tentativa de resultado (v.gr. arts. 193-194 LGT)-, pues se responsabiliza del pago de una sanción por la comisión de una previa infracción tributaria, sin infracción no habría sanción ni responsabilidad tributaria subsidiaria.

${ }^{62}$ Recordemos que cabría incardinar en el supuesto del art. 179.2.d) LGT los complicance programs (programas de autorregulación corporativa), tan en boga en el ámbito penal.

${ }^{63}$ Comentando el novedoso supuesto de responsabilidad del art. 43.2 LGT, se expresa que la nueva norma pretende cubrir una laguna existente hasta el instante actual en sede de nuestro ordenamiento, dado que la presentación de una autoliquidación tributaria correcta por parte de una entidad jurídica impide la derivación de la responsabilidad a sus administradores ex artículo 43.1 a) de la LGT, al comportar, a priori, la inexistencia de una conducta infractora. De Miguel Arias, S.: El nuevo supuesto de responsabilidad tributaria de administradores de personas jurídicas del artículo 43.2 de la LGT, Revista Quincena Fiscal, núm. 12/2013, BIB 2013\1287; Como es conocido, el artículo 43.1 a) declara responsables subsidiarios de la deuda tributaria a los administradores de hecho o de derecho de las personas jurídicas que, habiendo éstas cometido infracciones tributarias, no hubiesen realizado los actos necesarios que sean de su incumbencia para el cumplimiento de las obligaciones y deberes tributarios, hubiesen consentido el incumplimiento por quienes de ellos dependan o hubiesen adoptado acuerdos que posibilitasen las infracciones. Su responsabilidad también se extenderá a las sanciones. SÁNCHEZ PEDROCHE, J. A.: Primeras y preocupantes impresiones ...op. cit. pág. 105; MONTERO DOMÍNGUEZ, A.: Nuevas medidas en la lucha contra el fraude fiscal. Incidencia en la Ley General Tributaria, Carta Tributaria-Monografías, núm. 17, 2012, pág. 6; BAS SORIA, J., "Un nuevo supuesto de responsabilidad subsidiaria. Administradores de las personas jurídicas que presenten reiteradamente declaraciones tributarias sin ingreso", Revista ACEF (Asociación de Antiguos Alumnos del Centro de Estudios Financieros), 2012 (revista digital).

${ }^{64}$ La cuestión relativa a la repercusión que la existencia de consejeros delegados pueda tener en la responsabilidad del resto de los administradores de una sociedad no puede ser resuelta en el sentido de que la existencia de consejeros delegados releva de responsabilidad a los otros miembros del consejo de administración...los consejeros delegados son simplemente administradores a los que se delega alguna facultad 
de que «no hubiesen realizado los actos necesarios que sean de su incumbencia ${ }^{65}$ para el cumplimiento de las obligaciones y deberes tributarios», pero nunca respecto los supuestos de consentimiento por quienes de ellos dependan -puesto que son administradores de facto, no de iure, por lo que mal va a poder depender de ellos, orgánica o funcionalmente, nadie de esa sociedad-, ni tampoco podrán adoptar ellos acuerdos -salvo los supuestos de cargos caducados ${ }^{66}$ - que posibiliten las infracciones. Debemos comprender que los acuerdos entre administradores de hecho y terceros (v.gr. asesores fiscales) no deben de poder servir siempre de escudo ante la Administración para excusar su responsabilidad convirtiendo al tercero en administrador de hecho ${ }^{67}$. En cualquier caso, la acción administrativa sólo se dirigirá

concreta, sin perjuicio de la existencia de facultades indelegables, sin que la Ley vincule dicha delegación a la exigencia de una responsabilidad frente a terceros. La responsabilidad de los administradores es personal y los consejeros delegados no son una modalidad o género distinto del órgano de administración, sino que son apoderados subordinados a un consejo de administración con el que comparten las facultades delegadas y la responsabilidad inherente a las mismas, en los términos previstos en las leyes. En definitiva, que la responsabilidad subsidiaria de los administradores de las sociedades contemplada en el párrafo primero del apartado 1 del art. 40 de la Ley General Tributaria es personal y solidaria entre sí, sin que la existencia de un consejero delegado exima de responsabilidad a los demás administradores que hubieran incumplido sus obligaciones tributarias. La pertenencia al consejo de administración (aunque quede probada la no participación en la gestión ordinaria de la mercantil) es suficiente para declarar a los administradores responsables subsidiarios de las deudas de la entidad mercantil con base en el art. 40.1, párrafo primero, de la LGT, pues la comisión de infracciones tributarias por la sociedad administrada es suficiente para denotar una falta de diligencia, en forma de culpa in eligendo o in vigilando del administrador «nominal», en el cumplimiento de las funciones propias de su cargo, debiendo responder frente a la sociedad y frente a los acreedores sociales del daño que causen por actos contrarios a la Ley o a los estatutos o por los realizados sin la diligencia con la que deben desempeñar el cargo. Martínez Micó, J. G.: El alcance de la responsabilidad...op. cit.

${ }^{65}$ Así la STSJ Extremadura 20.9.2005, prolijamente, diferencia al empresario en sentido económico y jurídico, considerando que administrador lo es en tanto que encargado de velar por la gestión de la sociedad, aunque de hecho no lleve a cabo la mayoría de las operaciones de gestión, pero no por ello deja de ser administrador.

${ }^{66}$ Cohonestando nuestro criterio con el parecer jurisprudencial mayoritario (por todas, la STSJ Extremadura de 20.9.2005) que permiten la válida actuación de administradores con cargo caducado. Aunque nosotros entendemos que, salvo en estos supuestos de cargos de administradores con vicios formales o sustantivos, en el resto de supuestos no resultará sencillo que esos administradores adopten aparentemente acuerdos.

${ }^{67}$ De este parecer es Carbajo Vasco, D.: Algunas consideraciones sobre la responsabilidad en la nueva LGT, Crónica Tributaria, núm. 115, 2005, pág. 96; Desde otro punto de vista, Navarro Egea piensa que la referencia legal al administrador de hecho atenúa el efecto perverso que puede producirse como consecuencia de la compatibilidad con el supuesto de responsabilidad solidaria por la colaboración en las infracciones tributarias a que se refiere el art. 42.1.a) LGT, dado que nada impide que, si un sujeto no puede ser calificado de administrador a efectos de derivar 
contra el administrador o administradores de hecho por ausencia o imposible determinación de los de derecho, o cuando se acredite que éstos constituyen mera interposición ficticia.

Sólo cuando se reconoce personalidad jurídica sin un sustrato social que lo justifique, cuando la voluntad de la sociedad es en realidad la voluntad de sus miembros, resultará artificial imputar las sanciones a la persona jurídica. Entonces se puede llegar a dudar de la responsabilidad de los administradores en un segundo término respecto de la persona jurídica, priorizando, no sin un cierto desajuste respecto de las posibilidades de acción directa de los acreedores de la sociedad contra el administrador, conferidas por la regulación mercantil societaria, por lo que podría dudarse de si la falta de resolución de los problemas, que plantea el ejercicio de esta acción directa por la Administración tributaria acreedora, por sí o por los cauces procesales de derecho común, puede llevarnos a admitir que «la Hacienda Pública estatal pueda -no que deba- ejercitar cualesquiera acciones judiciales que sean precisas para la mejor defensa de sus derechos» (art. 8 de la Ley 47/2003, de 26 de noviembre, General Presupuestaria -LGP). Con ello ponemos de manifiesto la posibilidad de que la Administración deba ejercitar necesariamente la potestad de derivar su acción contra los responsables o pueda optar por acudir a la vía de las acciones rescisorias.

La responsabilidad y culpabilidad -en grado de dolo ${ }^{68}$ y no de cul$\mathrm{pa}^{69}$ - de los administradores deberá ser demostrada por parte de la Administración, debiendo concedérseles trámite de audiencia previo ${ }^{70}$ a la derivación de cualquier responsabilidad a los mismos, a fin de poder demostrar su inocencia, entendiendo que no resulta apropiado el régimen regulatorio actual ${ }^{71}$ para poder modular la graduación de la

responsabilidad por esta vía, la Administración pueda intentar reconducir su actuación hacia la figura del causante o colaborador que introduce el citado precepto. El responsable...op. cit. pág. 114.

${ }^{68}$ Así los entendemos de las conductas y verbos a que se refiere el art. 43.1.a) LGT.

${ }^{69}$ Algún autor sí admite la responsabilidad en grado de dolo o culpa o negligencia por «omisión de aquella diligencia que exija la naturaleza de la obligación y corresponda a las circunstancias de las personas del tiempo y del lugar», definida en el artículo 1.104 del Código Civil. Martínez Alonso, J. I.: La responsabilidad solidaria y subsidiaria en los tributos. Rev. Auditoría Pública, núm. 17, julio, 1999, pág. 48.

${ }^{70}$ ANÍBARRO PÉREZ, S.: El principio de culpabilidad en las infracciones tributarias, VVAA, Estudios de Derecho Financiero y Tributario en homenaje al profesor Calvo Ortega, Valladolid, Lex Nova, 2005, Tomo I, págs. 84-85.

${ }^{71}$ Así la jurisprudencia declara que no es posible individualizar la culpa en unos administradores y eximir a otros, ni siquiera cuando se hubiera encargado la gestión administrativa a un consejero-delegado (STSJ Canarias, 7.7.2005), siendo la responsabilidad subsidiaria entre administradores personal y solidaria entre sí, sin que la 
responsabilidad que se impute a cada administrador, por su intervención en el tiempo y momento del hecho -de modo que no pecharán por lo anterior los administradores posteriores en el tiempo ${ }^{72}-$, sobre todo cuando el hecho ser consejero de una sociedad no convierte automáticamente a dicha persona en responsable ${ }^{73}$.

De las sanciones tributarias posteriores a la apertura del proceso de liquidatorio responderán los liquidadores o la administración concur$\mathrm{sal}^{74}$ que hayan asumido funciones de administrador ${ }^{75}$ en los términos prevenidos por el art. 43.1. a) y c) LGT; lo que responde a la posibilidad de que la entidad prosiga su actividad durante el proceso de liquidación, sometiéndose pues al régimen fiscal de las activas o en funcionamiento. De haberse producido la extinción de la entidad, la responsabilidad por las deudas tributarias será exigible a los sucesores definidos por el art. 40, aún cuando las adjudicaciones resultantes de las operaciones liquidatorias se hagan a los mismos liquidadores, sin perjuicio de la responsabilidad subsidiaria comentada. Cabe, sin embargo, que la extinción de la entidad no excluya la continuación de sus actividades por otras personas, físicas o jurídicas, resultando entonces de aplicación la responsabilidad establecida por el art. 42.1.c LGT.

En cuanto a la figura del administrador responsable ${ }^{76}$, y considerando que la responsabilidad pueda atribuirse al administrador vigen-

existencia de consejeros delegados exima a los demás administradores que hubieren incumplido sus obligaciones (RTEAC 5.5.2005).

${ }^{72}$ El régimen jurídico por el que se rige la responsabilidad de los administradores es el vigente en el momento de producirse los hechos generadores de la misma y si el hecho generador es la comisión de infracciones tributarias será éste el momento determinante ( SAN 13 de junio de 2005 ).

${ }^{73}$ SsTSJ Extremadura 29.4.2002 y 22.10.2002.

${ }^{74}$ "Los integrantes de la administración concursal» se regulan en el título II Ley Concursal (LC) -«de la administración concursal»-, y por lo tanto comprende a los administradores concursales (art. 27 LC) y a los llamados «auxiliares delegados», nombrados por el juez a solicitud de aquel para que ejerzan determinadas funciones delegadas cuando la complejidad del concurso así lo exija (art. 32 LC).

${ }^{75}$ En cuanto a «obligaciones y sanciones posteriores» a esta situación, la equiparación de la responsabilidad de los «integrantes de la Administración concursal» a la de los administradores, cuando tengan atribuidas funciones de administración, resulta desconcertante, pues parece responder a la legislación anterior, en la que tales deudas y sanciones tenían carácter de «extra concursales» y, por lo tanto, no podían verse afectadas por la conducta de los síndicos o interventores.

${ }^{76}$ Ante situaciones de falta de acceso a registro de cese o nombramiento de administradores, hemos de tener en cuenta que el principio de legitimidad registral opera como una presunción iuris tantum, admitiendo prueba en contrario -presentando, v.gr., el título no inscrito-, surtiendo efectos el nombramiento de administrador desde su aceptación y no desde su inscripción, que no tiene carácter constitutivo. En todo caso, puede darse el caso que el administrador ya cesado y considerado responsable tributario, tras un prolongado lapso temporal, se le derive dicha responsabilidad 
te durante los plazos reglamentarios, fijados en los distintos tributos, o períodos en donde se consuman la conductas infractoras tipificadas en la norma, nos surgen dudas cuando exista un cambio de administrador durante el tiempo que media entre el devengo del tributo y el período reglamentario establecido para su declaración, dependiendo de donde se encuentre la infracción si en los registros contables o fiscales o en la propia declaración elaborada, o supuestos en los que el nuevo administrador asume, como ciertos, datos de administradores anteriores cuya falta de veracidad desconocía. Los ejemplos pueden ser múltiples, por lo que habrá que analizar muy detenidamente cada supuesto, en los que resulta necesario el trámite de audiencia para poder ejercitarse una adecuada defensa.

\section{LOS SUPUESTOS DE LOS APARTADOS G) Y H) DEL ARTÍCULO 43.1 LGT}

En los supuestos contemplados en los apartados g) y h) del art. 43.1 LGT, introducidos por la Ley 36/2006, de 29 de noviembre, de Medidas de Prevención del Fraude Fiscal, se incorpora en el ámbito tributario la doctrina de levantamiento del velo (lifting of the veil o piercing the corporate veil doctrine ${ }^{77}$, en el derecho anglosajón ${ }^{78}$ ), con el fin

aunque podría generársele indefensión, por no disponer de los datos de la empresa con qué defenderse, y no poder la Inspección o la Administración Tributaria facilitarlos, pues debe guardar sigilo con lo obtenido, cuando, quizás, ese administrador podría ser parte de la compañías de la competencia.

${ }^{77}$ En el derecho anglosajón, la técnica del levantamiento del velo surgió como una aplicación de la facultad que, en determinados supuestos, concede la ley a los jueces para resolver basándose exclusivamente en la equidad. Nuestro ordenamiento (artículo 3.2 del Código civil) no contempla una facultad semejante, por lo que los tribunales han debido acudir a estas figuras genéricas, mal definidas o carentes de definición legal que, de forma acumulativa, se aplican por la jurisprudencia.

${ }^{78}$ Puede afirmarse que el primer caso del que se tiene noticia en el que se aplicó esta doctrina (disregard of the legal entity) fue el caso Bank of the United States vs. Deveaux en 1809, enjuiciado por el juez Marshall. Pérez Bernabeu, B.: Levantamiento del velo y responsabilidad tributaria, en el Proyecto de investigación «la Administración Tributaria en los procedimientos concursales: régimen jurídico de los créditos tributarios e implicaciones para la Hacienda Pública» (DER2012-33457), Ribes Ribes, A. (dir.), pág. 34; El primer precedente en el ámbito europeo, probablemente, fue la decisión de la Cámara de los Lores de 1897 del asunto Salomón vs Salomón \& Co (AC22). Boldó Roda, C.: Levantamiento del velo y persona jurídica en el Derecho Privado Español, Thomson-Aranzadi, Pamplona, 2006, págs. 85-ss; En España se acoge por la jurisdicción civil en las SsTS de 21.02.1969 y 28.05.1984, y desde allí se extiende a las jurisdicciones penal, administrativa y social. La STS de 28.5.1984 se calificó como histórica, con su precedente en la de 8.1.1980. De ángel Llagues, R.: La doctrina del levantamiento del velo de la persona jurídica, Civitas, Madrid, 1997, pág. 121. 
de dirigir la acción de la Administración, también, contra el responsable último, excepcionando así la regla general de la responsabilidad limitada. Hay que poner de manifiesto que la jurisprudencia civil ${ }^{79}$ más reciente -de donde proviene esta doctrina- no se muestra receptiva a la aplicación indiscriminada ${ }^{80}$ del levantamiento del velo. El legislador tributario la ha recibido con entusiasmo encomendando su ponderación a una de las partes del procedimiento, el funcionario que lo instruya (autotutela ${ }^{81}$ ), sin que a la otra parte le quede otro recurso más allá del jurisdiccional. El recurso excepcional ${ }^{82}$-al que acudir cuando no sirvan otras herramientas para impedir la elusión fiscal-, comedido $^{83}$-sin forzar los institutos jurídicos ni abusando de sus formas jurídicas-, razonable ${ }^{84}$ y prudente ${ }^{85}$ a esta doctrina se producirá

${ }^{79}$ Esta sentencia [Sentencia del Tribunal Supremo (Sala Primera) de 28 de mayo de 1984] hace referencia a todas las figuras que el Título preliminar del Código civil configura como límites genéricos de la norma jurídica lo que, en nuestra opinión significa que el alto tribunal no tiene claro cuál es el fundamento de su resolución, pero sí la justicia de la misma. En otros términos, que el levantamiento del velo es una técnica para lograr la justicia material, que se utiliza cuando no existe otro instrumento jurídico adecuado. De ahí su carácter de «último recurso». Echevarrieta Sazatornil, J. M. ${ }^{\text {a: }}$ Los nuevos supuestos de responsabilidad, Quincena Fiscal, núm. 17/2008, BIB 2008\2119.

${ }^{80}$ Más bien se muestra restrictiva con el uso de esta doctrina. STS 29.6.2006.

${ }^{81}$ Cuyo privilegio en ciertos casos, como el del concurso, le otorga cierta ventaja sobre otros acreedores que deben de esperar a que sea el juez quien dictamine.

${ }^{82}$ Carece de sentido que, durante un proceso de inspección, encaminado a determinar la deuda tributaria de un sujeto pasivo (y, en su caso, su sanción) persona jurídica, el órgano de inspección al aplicar los arts. 12 a 16 LGT [que no son sino otros mecanismos anti-elusión] no determine la condición del verdadero deudor tributario oculto por simulación o fraude, y, sin embargo, más tarde, en fase de recaudación, acuda a la doctrina del levantamiento del velo.

${ }^{83}$ Estos supuestos de responsabilidad, inspirados en la legislación británica podrían plantear problemas de proporcionalidad precisamente por su aplicación en cualquier sector del tráfico jurídico (recuérdese que la norma británica se aplicaba sólo al comercio de ciertas mercancías en las que frecuentemente se producían supuestos fraudes en cadena, mientras que la norma española se aplica a cualquier adquisición... Martín Jiménez, A.: La responsabilidad tributaria en la LGT y el Derecho comunitario, IEF, Madrid, Documento núm. 2/09, pág. 72.

${ }^{84}$ Debemos tener en consideración que, en vía civil, los tribunales levantan el velo en defecto de precepto legal aplicable, atendiendo a razones de equidad, por lo que un cierto grado de flexibilidad conceptual es consustancial a la propia razón de ser de esta técnica, lo que casa mal con los principios del derecho tributario y peor aún con los del derecho sancionador.

${ }^{85}$ Así en las SsTS 28.5.1984, 12.6.1995, 25.6.2002, 9.3.2005, 29.7.2005, entre otras; Ruiz Hidalgo opina que con la regulación de la LGT se sustrae a los órganos judiciales la aplicación excepcional y subsidiaria de la doctrina del levantamiento del velo, para que sea la Administración tributaria la que de una manera «ordinaria» aplique esta doctrina a través de un supuesto de responsabilidad tributaria. Por este motivos la regulación de la doctrina del levantamiento del velo supone una ampliación del conjunto de facultades de autotutela declarativa y ejecutiva aplicada de manera exorbitante y desorbitada, cuando se podía haber continuado con la aplicación jurispru- 
cuando no existan otros medios en el Ordenamiento Tributario para evitar los efectos nocivos de la personificación jurídica interpuesta indebidamente ${ }^{86}$.

La falta de claridad y de precisión de estas doctrinas, con la merma que conlleva al principio de seguridad jurídica, hace que le siga un incesante y crítico argumentario doctrinal, sin perjuicio que quepa

dencial del levantamiento del velo, pues la aplicación del principio de proporcionalidad por el juez permite realizar una interpretación correctiva de la norma. Ruiz Hidalgo, C.: Un ejemplo de cláusula antielusiva en el procedimiento de recaudación: la responsabilidad por levantamiento del velo, en VII Jornada Metodológica de Derecho Financiero y Tributario Jaime García Añoveros. Interpretación del Derecho Financiero y Tributario. La asignatura de Derecho Financiero y Tributario en los nuevos planes de estudio, IEF, Documento 12/2011, pág. 502; Ruiz Hidalgo, C.: La responsabilidad por levantamiento del velo como cláusula antielusiva, Quincena Fiscal, núm. 3, feb (I), 2011, pág. 61.

${ }^{86}$ La sociedad ha pasado a ser una segunda identidad que puede obtener y utilizar a su antojo cualquier persona, aunque ello no implica por sí solo un propósito ilícito. El mismo sistema jurídico que rechaza que una persona disponga de dos o más personalidades (dos o más documentos nacionales de identidad), acepta sin problemas que actúe a través de cuantas sociedades desee... Las facilidades para la creación de personas jurídicas han sido aprovechadas para la defraudación, tanto en general como específicamente tributaria. Las técnicas empleadas son diversas, pero básicamente responden a dos tipos: aplicar un régimen tributario más favorable (el Impuesto sobre Sociedades o algunas particularidades del mismo, no aplicables a las personas físicas) o imputar la deuda tributaria a una persona distinta del titular de los bienes y derechos que, de no ser por la barrera que supone la diferente personalidad jurídica, permitirían su satisfacción, burlando así el principio de responsabilidad patrimonial universal (artículo 1911 del Código civil). Este segundo tipo es el que nos interesa... Ahora bien, entendemos que la pasividad administrativa ha dado carta de naturaleza a lo que en realidad es un fraude, la utilización de sociedades que son tan sólo una inscripción en el Registro Mercantil, sin un sustrato real y sin viabilidad alguna, y que esta situación ha sido bendecida por el legislador... La Ley 36/2006 contempla una medida muy criticada: la posibilidad de que la Administración revoque el Número de Identificación Fiscal, lo que impide nuevas inscripciones relativas a la sociedad en el Registro Mercantil. Obsérvese que se trata de una medida relativa al ámbito fiscal, aunque con consecuencias fuera de él, lo que significa que el legislador no ha querido llevar hasta sus últimas consecuencias lógicas la desvalorización de las entidades creadas sólo para defraudar: se reconoce su personalidad jurídica, aunque se elimina su posibilidad de actuar. Echevarrieta Sazatornil, J. M. a.: Los nuevos supuestos...op. cit. 
calificar estas doctrinas como un despropósito ${ }^{87}$, dislate ${ }^{88}$ o misil dirigido a la línea de flotación del ejercicio de las actividades profesionales a través de sociedades ${ }^{89}$ - algo que no puede arrumbar la normativa fiscal, so pena de ignorar las categorías mas elementales del derecho, como la persona jurídica y la realidad de la sociedad-. De este modo, la utilización de esa doctrina en un supuesto de responsabilidad tributaria resultará contradictorio ${ }^{90}$, especialmente si atendemos al hecho de que se ha juridificado y configurado mediante dos supuestos de responsabilidad tributaria. Esta contradicción se justifica en que si la doctrina del levantamiento del velo descansa en la idea de que el verdadero deudor (infractor) se esconde tras la existencia de una persona jurídica ${ }^{91}$, resulta innecesaria la previa declaración de

${ }^{87}$ Es contradictorio utilizar un supuesto de responsabilidad que, por definición, implica que el responsable se sitúa junto a, en un caso donde precisamente de lo que se trata es de dilucidar quién está detrás de la estructura societaria, levantando el velo de la protección jurídica. En otras palabras, si hay levantamiento del velo, donde antes había dos personas ahora habrá sólo una, por lo que utilizar el instituto de la responsabilidad implica asumir que sigue habiendo dos, algo de todo punto contradictorio con el concepto mismo de levantamiento del velo. Martín Jiménez A.: Los supuestos de responsabilidad en la LGT (Hacia una configuración constitucional y comunitaria de la responsabilidad tributaria), Thomson-Aranzadi, Madrid, 2007, pág. 347; En igual sentido, López López, H.: La responsabilidad tributaria por «levantamiento del velo" (una errónea articulación normativa para una discutible doctrina jurisprudencial), Univ. Carlos III, BOE, Madrid, 2009, pág. 61.

${ }_{88}$ Considerando que con este levantamiento del velo se va a determinar una responsabilidad de segundo grado, más propia de sociedades personalistas, desconociendo así el significado del patrimonio de la persona jurídica. García Novoa, C.: El proyecto de Ley de prevención del fraude (II), Quincena fiscal, núm. 10, 2006, pág. 19.

${ }^{89}$ GARCÍA NOVOA, C.: La ofensiva contra las sociedades profesionales, Jurisprudencia Tributaria, Aranzadi, núm. 12, 2006.

${ }^{90}$ SÁNCHEZ HUETE, M. A.: El levantamiento del velo (la responsabilidad de la sociedad pantalla y refugio), Marcial Pons, Madrid, 2008, págs. 75 y 310.

${ }^{91}$ La sentencia del Tribunal Supremo de 29 de junio de 2006 enumera los siguientes caracteres como elementos de esta figura: $1 .^{\circ} \mathrm{La}$ doctrina del levantamiento del velo trata de evitar que el abuso de la personalidad jurídica pueda perjudicar intereses públicos o privados, causar daño ajeno o burlar los derechos de los demás. $2 .{ }^{\circ}$ Se trata, en todo caso, de evitar que se utilice la personalidad jurídica societaria como un medio o instrumento defraudatorio, o con un fin fraudulento. 3 . $^{\circ}$ Se produce dicho fin fraudulento, entre otros supuestos, cuando se trata de eludir responsabilidades personales, y entre ellas el pago de deudas; y $4{ }^{\circ}{ }^{\circ}$ Sin embargo, siempre habrá de tenerse en cuenta que la doctrina del levantamiento del velo es de aplicación excepcional, por lo que debe ser objeto de un uso ponderado y restringido. Así pues, los puntos esenciales son dos: el abuso de la forma societaria y el daño a terceros. Tal como señala la sentencia de 14 de septiembre de 2006: La idea básica es que no cabe la alegación de la separación de patrimonios de la persona jurídica por razón de tener personalidad jurídica, cuando tal separación es, en la realidad, una ficción que pretende obtener un fin fraudulento, como incumplir un contrato, eludir la responsabilidad contractual o extracontractual, aparentar insolvencia... Curiosamente, la doctrina del Tribunal Supremo parece no tomar en consideración que, en nuestro derecho, la personalidad jurídica no lleva necesariamente aparejada la limitación de 
fallido del deudor, puesto que la persona contra la que se dirige la acción de cobro es el auténtico deudor (infractor), y, también, obligado al pago de una deuda (sanción) de la que tuvo conocimiento desde su generación. Resultará paradójica, a efectos de proceder a derivar la responsabilidad al administrador, la continuación en la actividad económica del deudor principal (infractor), lo que dificultará su declaración de fallido (art. 176 LGT), al ser factible en tal caso que existan bienes embargables que permitan el cobro de la deuda tributaria ${ }^{92}$. Es más, a la vista de esta circunstancia devendría más útil esta responsabilidad, subsidiaria precisamente, en el supuesto contrario, esto es, cuando la empresa cesa ${ }^{93}$.

Desde nuestro punto de vista, más que una incorporación de la doctrina del velo propiamente dicha, lo que se incorpora es la primigenia versión de la «doctrina de terceros ${ }^{94}$, de modo que lo que realmente se trata de paliar es la creación de una sociedad como figura tercera con el fin de incumplir determinadas obligaciones. Es más existe un claro parentesco o proximidad conceptual entre la simulación y la figura del levantamiento del velo, pudiéndose considerar ésta como una especie del género simulación, con la especificidad de versar sobre la utilización de una persona jurídica ${ }^{95}$, lo que podría hacer innecesaria la existencia de los apartados del precepto estudiado, aunque considerando su existencia legal, este artículo ejerce, si no un entorpecimiento con otros supuestos de responsabilidad tributaria, de seguro sí una especie de vis atractiva ${ }^{96}$ sobre los supuestos de los artículos 43.1.a) LGT -por la responsabilidad de los administradores de hecho- o del art. 42.1.a) LGT. El principio de especialidad habrá de llevar a aplicar la norma especial frente a la de carácter general. El

responsabilidad, sino que ésta es un beneficio adicional. Así, en las sociedades colectivas, que tienen personalidad jurídica, los socios responden de las deudas sociales. En consecuencia, lo que en rigor produce el levantamiento del velo no es el desprecio de la personalidad separada de la sociedad (disregard of the legal entity), sino la denegación de la limitación de responsabilidad. Y éste es precisamente el efecto que produce la responsabilidad subsidiaria. Echevarrieta SazatorniL, J. M. ${ }^{\text {: }}$ Los nuevos supuestos...op. cit.

${ }^{92}$ DE MIGUEL ARIAS, S.: El nuevo supuesto de responsabilidad...op. cit.

${ }^{93}$ SÁNCHEZ PEDROCHE, J. A.: Primeras y preocupantes impresiones ... op. cit., pág. 106.

${ }^{94}$ En el ámbito civil tuvo uno de sus primeros reflejos en las SsTS de 7.6.1929 y 8.10.1929. PUIG BRUTAU J.: Apariencia y realidad en las sociedades mercantiles: el abuso del Derecho por medio de las personas jurídicas. Ed. Ariel, Barcelona, 1958.

${ }^{95}$ SÁNCHEZ HUETE, M. A.: El levantamiento del velo...op. cit. págs. 75-76.

${ }^{96}$ Esta característica se ha puesto de manifiesto por MARTíNEZ LAGO M. A. y Almudí Cid, J. M:: Autotutela tributaria, levantamiento del velo y derivación de la responsabilidad a las sanciones, Rev. Contabilidad y Tributación, CEF, núm. 296, 2007, pág. 24. 
supuesto de desviación patrimonial ${ }^{97}$ (art. 43.1.g LGT) debe tener carácter especial frente a la colaboración genérica en la transmisión u ocultación de bienes o derechos (art. 42.2 LGT), mientras el supuesto de unicidad de personas (art. 43.1.g) LGT) lo tendría frente a la sucesión del artículo 42.1.c) de la Ley General, en cuanto éste contempla tres supuestos distintos de sucesión ${ }^{98}$.

Estos redundantes ${ }^{99}$, imprecisos y farragosos ${ }^{100}$ preceptos, de naturaleza sancionadora ${ }^{101}$, tienen como objetivo la corrección de la abusiva $^{102}$ utilización de la persona colectiva como sujeto de derecho

${ }^{97}$ En el caso de transmisión fraudulenta a sociedades controladas por el deudor principal, o en las que concurra una voluntad rectora común, sin embargo, esa referencia (al art. 42.2.a LGT) lo será a los únicos efectos de precisar las diferencias y relaciones entre ambos supuestos de responsabilidad tributaria. GONZÁLEZ ORTIZ, D.: La transmisión de bienes en fraude de acreedores como presupuesto de responsabilidad tributaria, Quincena Fiscal, núm.18/2012, BIB 2012\3070.

${ }^{98}$ En sentido contrario, la jurisprudencia ha declarado claramente que la técnica del levantamiento del velo tiene el carácter de último recurso, utilizable exclusivamente cuando no existe otra vía para lograr la satisfacción de la deuda tributaria. A partir de esta consideración que, desde luego, no aparece plasmada en la norma positiva, también llegaríamos a la conclusión de que la aplicación los supuestos contemplados en el artículo 42 de la Ley ha de ser prioritaria frente a los del artículo 43.1, g) y h). La ventaja que puede presentar este supuesto de responsabilidad (artículo 43.1, g) y h) LGT] frente al previsto en el artículo 42.1.c) de la Ley General Tributaria es que permite dirigirse directamente contra la persona que está detrás de toda la cadena de sucesiones, sin necesidad de remontar ésta ni de que dicha persona haya, a su vez, ejercido la actividad en su propio nombre. Y, en cuanto a la responsabilidad de quien colabora en la ocultación (art. 42.2 LGT), los nuevos supuestos de responsabilidad subsidiaria [artículo 43.1, g) y h) LGT] permiten exigir la totalidad de la deuda tributaria, sin verse limitados por el valor de los bienes o derechos transmitidos u ocultados.

${ }^{99}$ PÉREZ ROYO, F.: Derecho Financiero y Tributario. Parte General, 16. ${ }^{a}$ ed. Civitas, Madrid, 2006, págs. 172-173.

${ }^{100}$ MARTÍN JIMÉNEZ, A. L.: La responsabilidad por contratas y subcontratas, el Derecho Comunitario y el Anteproyecto de la Ley de Prevención del Fraude: un apunte, Aranzadi, Jurisprudencia Tributaria, núm.. 15-22, 2005, pág. 131.

${ }^{101}$ Estos supuestos de responsabilidad lo que vienen a tipificar son sanciones. Cayón Galiardo, A.: El proyecto de Ley de Medidas para la Prevención del Fraude Fiscal: otro enfoque, Rev. Técnica Tributaria, núm. 72, 2006, pág. 16; En contra, considerando que lo que hay es una identidad de sujetos, si bien disimulada, en un abuso de personalidad jurídica, Martín Jiménez, A.: Los supuestos de responsabilidad en la LGT (Hacia una configuración constitucional y Comunitaria de la Responsabilidad Tributaria), ThomsonAranzadi, 2007, págs. 347-348; También se posiciona en contra del carácter sancionador de la norma, PÉREZ BERNABEU, B.: Levantamiento del velo...op. cit. pág. 70.

${ }^{102}$ Se presenta como una específica "cláusula antiabuso», expresiva de un presupuesto de responsabilidad basado en el control dominante o efectivo de unas personas sobre otras, la voluntad rectora común a ellas o la confusión de sus esferas personales y económicas, como medio de elusión o desviación de responsabilidades. Pero ello no obsta a integrar sistemáticamente dicha cláusula en el marco de los institutos y preceptos generales, previstos para garantizar la aplicación efectiva del ordenamiento jurídico (arts.6 y 7 CC) y de las particulares del ámbito tributario, donde la LGT contemplando expresamente la simulación (art. 16 LGT) y el fraude de ley, 
-fictio iuris de legitimidad fundada en derecho de asociación de las personas naturales para actuar sus intereses o fines comunes o colectivos- como pantalla formal vacía de sustancia para eludir o burlar responsabilidades ante terceros. Así debemos considerar que no existe un solo tipo de doctrina del levantamiento del velo, ni siempre en fase de recaudación ${ }^{103}$, aunque todas tengan origen societario, y no siempre encuentren fácil encaje en materia tributaria, sobre todo por la pobre técnica jurídica consistente en mezclar el levantamiento del velo con la responsabilidad tributaria, cuando esta doctrina podría obviarse utilizando otras técnicas anti-abuso (arts. 15-16 LGT) ${ }^{104}$-técnicas cuya aplicación parece que se trata de eludir ${ }^{105}-$, pues no son sino casos de fraude de ley tributaria ${ }^{106}$, que requieren de una labor

como instituto de aplicación a todas las ramas de dicho ordenamiento jurídico, también lo es a este ámbito (SSTC 37/1987, 37 y 120/2005, de 20 de mayo,), sin perjuicio de su formulación mediante cláusulas antiabuso (art. 15 LGT, entre otros).

${ }^{103}$ No obstante la aplicación del mecanismo del levantamiento del velo tanto en la fase de liquidación como en el procedimiento de recaudación ni ha sido pacífica ni ha tenido comienzos parejos en el tiempo.... ZORNOZA, considera legalmente inadmisible ...la aplicación de la doctrina del levantamiento del velo para la determinación de las cuotas tributarias (fase de liquidación)...no han faltado pronunciamientos jurisprudenciales que apliquen la doctrina del levantamiento del velo en el ámbito de la recaudación tributaria, pero destaca por encima de todos ellos la Sentencia de la Sala 3. ${ }^{a}$ del Tribunal Supremo de 19 de abril de 2003. Pérez Bernabeu, B.: Levantamiento del velo...op. cit. págs. 40-43; La propia Exposición de motivos de la Ley 36/2006 aclara que constituye un hito en el ámbito de la reacción frente a las estrategias de fraude en fase recaudatoria.

${ }^{104}$ Incluso algunas de carácter penal como la insolvencia punible (arts. 257-261 CP). FALCÓN Y TELLA, R.: Otras medidas para la prevención del fraude contenidas en la Ley 36/2006, de 29 de noviembre (II). Quincena Fiscal, 2007, núms.. 3-4, pág. 9.

${ }_{105}$ Como indica la propia Exposición de Motivos de la Ley 36/2006, refiriéndose a la STS 19.04.2003, donde se barajó un fraude de ley en fase recaudatoria. Sin embargo, considerando el complejo procedimiento de las normas antiabuso, y la imposibilidad de aplicar sanciones a los casos de fraude, se comprende porqué la Administración prefiera normas vagas como la del levantamiento del velo, de aparente sencilla aplicación. Algún autor critica que en caso de fraude no se pueda sancionar, comparando el sistema patrio con el extranjero. Los administradores de sociedades como responsables tributarios RUIZ ALMENDRAL, V.: Tratado sobre la Ley General Tributaria: Homenaje a Álvaro Rodríguez Bereijo / coord. por Andrés Báez Moreno, Domingo Jesús Jiménez-Valladolid de L'Hotellerie-Fallois; Juan Arrieta Martínez de Pisón (dir.), Miguel Angel Collado Yurrita (dir.), Juan Zornoza Pérez (dir.), Vol. 1, 2010 (Tomo I), ISBN 978-84-9903-468-3, págs. 1052-1053.

${ }^{106}$ La jurisprudencia al aplicar la construcción normativa del fraude a la ley, ha recurrido al levantamiento del velo como técnica instrumental para demostrar la artificiosidad de la conducta elusiva. En este sentido fue pionera la STS de 19 de abril de 2003, que declaró por primera vez la compatibilidad el recurso al fraude de ley y el levantamiento del velo...no obstante aboga por una aplicación excepcional del levantamiento del velo, alejada de una aplicación de carácter absoluto y exenta de límites, prefiriendo su aplicación en los supuestos expresamente previsto por el legislador. No obstante, destaca por ser el primer pronunciamiento que establece una relación directa entre el fraude de ley y la doctrina del levantamiento del velo, la SAN de 29 de marzo 
de exégesis normativa. Nos debemos de tomar muy en serio el carácter restrictivo ${ }^{107}$ del recurso práctico ${ }^{108}$ a la analogía a través de interpretaciones teleológicas -no restrictivas en el ámbito de su cerco-, de modo que no resulta apropiado utilizar fórmulas vagas e indeterminadas a modo de cajón de sastre para abarcar todo aquello que no cabe regular o recoger en preceptos concretos, de modo que sea el aplicador del derecho quien lo dote de contenido real o colmate la laguna legal. En cualquier caso hemos de tener muy en cuenta el carácter autónomo del ordenamiento tributario, que no resulta estricta y necesariamente vinculado por el Derecho privado (STC 45/1989) ${ }^{109}$, y que habrá de ser la Administración la que pruebe cada uno de los prerrequisitos para que se dé cada supuesto.

. El supuesto del apartado g) del art. 43.1. ${ }^{\circ}$ LGT impone el «levantamiento del velo» [directo $\left.{ }^{110}\right]$ de las "personas jurídicas», traspasando su personalidad para alcanzar a las «personas o entidades»-incluyendo pues los entes del art. 35.4 LGT- que las dominan o controlan o, en definitiva, actúan a través de aquellas, por lo que les resulta imputable $^{111}$ la correspondiente responsabilidad. Sin embargo, detectamos

de 2006, al relacionar el levantamiento del velo con la apreciación de «formas jurídicas insólitas y desproporcionadas»... No obstante esta relación, es oportuno recordar que la Administración no puede unilateralmente proceder a la aplicación del levantamiento del velo cuando aplique el artículo 15 LGT, ya que ésta únicamente puede proceder a levantar el velo si la norma expresamente lo prevé, cosa que no sucede con el artículo 15 LGT. PÉREZ BERNABEU, B.: Levantamiento del velo...op. cit. págs. 52-55.

${ }^{107}$ Por último, cabe formular una reflexión: ¿no sería preferible replantear los requisitos para la atribución de la personalidad jurídica diferenciada y del privilegio de limitación de responsabilidad, a fin de evitar el fraude, sancionando directamente el incumplimiento de tales requisitos con la pérdida de dicha limitación, en lugar de buscar una forma indirecta de obtener el mismo efecto? En nuestra opinión, la seguridad jurídica saldría claramente beneficiada. ECHEVARRIETA SAZATORNIL, J. M. ${ }^{\mathrm{a}}$ : Los nuevos supuestos...op. cit.

${ }^{108}$ Atajo, por el que la propia Administración Tributaria, al amparo de la autotutela administrativa, procederá a declarar ella misma esa responsabilidad, descorriendo el velo de la sociedad sin esperar a su declaración judicial, con lo que se conseguirá una mayor efectividad de la norma. López López, H.: La responsabilidad tributaria por levantamiento del velo. (Una errónea articulación normativa para una discutible doctrina jurisprudencial), Univ. Carlos III, Madrid, y BOE, 2009, pág. 70; En contra, Martínez Lago M. A. y Almudí Cid, J. M:: Autotutela...op. cit. pág. 18.

${ }^{109}$ Resultando imperante la sustancia sobre la forma (substance over form).

${ }^{110}$ En terminología de SOLER ROCH, M. ${ }^{a}$ T.: Lifting the veil doctrine (Recent developments in Spanish Tax Law) A vision of taxes within and outside European borders: Festschrift in honor of Prof Dr. Frans Vanistendael, Alphen aan den Rijn: Kluwer Law International, 2008, págs. 831-846; Otros autores usan responsabilidad de la sociedad pantalla (letra g) o responsabilidad de la sociedad refugio (letra h). SÁNCHEZ HUETE, M. A.: El levantamiento del velo...op. cit.

${ }^{111}$ La nueva regulación de la Ley General Tributaria y de las Normas Forales Generales Tributarias de los Territorios Históricos de la Comunidad Autónoma del País 
una considerable imprecisión ${ }^{112}$ a la hora de conceptuar lo que deba entenderse por "control efectivo», control que además debe de ser total o parcial, directo o indirecto ${ }^{113}$, aunque el nivel de desacierto se acentúa más, sino incurre en incongruencia, cuando exige que el con-

Vasco se han preocupado también por establecer figuras que permitan luchar contra el fraude fiscal en la fase de recaudación, en el sentido que apunta esta sentencia del Tribunal Supremo, y así encontramos en la nueva Norma Foral 2/2005, de 10 de marzo, General Tributaria del Territorio Histórico de Bizkaia un supuesto tipificado de responsabilidad en la que se hace una aplicación en la Ley de la doctrina del «levantamiento del velo» a un caso concreto de elusión en la fase de recaudación de deudas tributarias liquidadas. Así, el apartado 3 del artículo 41 de la Norma Foral 2/2005, de 10 de marzo, General Tributaria del Territorio Histórico de Bizkaia dispone que: «Cuando los activos y organización empresarial necesarios para desarrollar una explotación o actividad económica estén formalmente distribuidos entre más de una persona física o jurídica, de forma que, siendo único el control efectivo, se oculte la realidad global de la empresa mediante la constitución de diversas entidades que posibiliten la elusión del pago de las deudas tributarias, responderán solidariamente con esos activos de la totalidad de la deuda tributaria y, en su caso, de las sanciones derivadas de la explotación o actividad económica, las diferentes personas físicas o jurídicas entre las que se encuentren repartidos aquéllos. Se presumirá que hay control efectivo cuando exista una participación en el capital social o en el patrimonio igual o superior a un 25\%, de manera directa o indirecta».... En cualquier caso, la aplicación de la doctrina del «levantamiento del velo», como cualquier cláusula general anti-abuso, debe aplicarse con mesura, prudencia y proporcionalidad, precisamente para no desnaturalizarla, y atendiendo a que su finalidad práctica es la evitación de abusos jurídicos o de violaciones indirectas de la normativa tributaria, y no debe convertirse en un instrumento justificador de cualquier práctica administrativa más o menos laxa, en la medida en que el hecho de que la Administración tributaria realice su labor dentro de un correcta y respetuosa aplicación de los procedimientos tributarios es una garantía ineludible para la correcta exacción de los tributos. Alonso Arce, I.: El «levantamiento del velo» en la fase de recaudación, Jurisprudencia Tributaria, Aranzadi paraf.núm.2613/2005, BIB 2005\2166.

112 Estos supuestos representan tal ambigüedad e imprecisión que difícilmente resultará constitucionalmente admisible este tipo de responsabilidad tributaria y menos aún respecto de las sanciones. LÓPEZ LÓPEZ, H.: La responsabilidad tributaria por levantamiento del velo...op. cit. pág. 73 .

${ }^{113}$ Más importante es, quizá, la referencia a un control directo o indirecto. Estas expresiones parecen apuntar a una participación en el capital ya sea directa, de la persona que controla la sociedad, ya indirecta, de una sociedad que es a su vez controlada por esa persona (lo que cuadra con la referencia a un control total o parcial, es decir, igual o inferior al 100 por 100 del capital). De acuerdo con esta interpretación, la responsabilidad tributaria por levantamiento del velo sería sólo aplicable a quien ostenta el control sobre la entidad de manera abierta, basada en una participación en el capital social o en los derechos políticos de la sociedad o de aquella entidad que participa en ésta. No obstante, esta interpretación no permitiría combatir los supuestos en que el control se produce mediante testaferros o sociedades controladas sin una participación formal en el capital, que son los que realmente suponen una apariencia fraudulenta de insolvencia, ya que en el caso de participación en el capital siempre es posible embargar y enajenar esta participación. Por ello nos inclinamos por entender que el control puede adoptar cualquier forma, tanto aparente como oculta, pues de otra forma la figura no es aplicable precisamente en los supuestos en que es más necesaria. Echevarrieta Sazatornil, J. M. ${ }^{\text {a }:}$ Los nuevos supuestos...op. cit. 
trol efectivo sea parcial, lo que casa mal con la propia efectividad del control, salvo que se entienda que dicho control parcial sea, además, indirecto por suponer un porcentaje del accionariado o capital social $^{114}$, aunque no debe, nunca, confundirse control con titularidad o participación $^{115}$, ni tampoco el control del que aquí se habla con el del régimen de consolidación fiscal establecido en la Ley 27/2014, de 27 de noviembre, del Impuesto sobre Sociedades (art. 58.2) ${ }^{116}$. Además deberá probar la Administración la carencia de objeto social real, legítimo y fundamentable racionalmente, así como la presencia de una finalidad consistente en la defraudación ${ }^{117}$ de los derechos de la Hacienda Pública ${ }^{118}$ (business purpose test). En caso de que, en fase probatoria, se desprendan que los motivos económicos fueron válidos, como también los fines reales y efectivos que ampararon la creación y la consecuente actuación empresarial, junto a las pretendidas y líci-

${ }^{114}$ Como ocurre en las Legislación Foral Alavesa (art. 42.3 Norma Foral 6/2005, de 28 de febrero, General Tributaria), o Guipuzcoana (Norma Foral 2/2005, de 8 de marzo, General Tributaria) o Vizcaína ( Norma Foral 2/2005, de 10 de marzo, General Tributaria), que presumen que existe control efectivo cuando exista una participación en el capital social o en el patrimonio igual o superior a un 25 por cien, de manera directa o indirecta.

${ }^{115}$ No parece que ejerza el control de la sociedad quien simplemente participa en ella y ejerce sus derechos de socio. Delgado Pacheco, A.: El levantamiento del velo en la Ley General Tributaria y en la aplicación del IVA, Noticias de la Unión Europea, núm. 280, 2008, pág. 22.

${ }^{116}$ Aunque así lo colma, aún de modo parcial, Castillo Solsona, M. ${ }^{a}$ M.: La paulatina ampliación de los supuestos de responsabilidad tributaria. La responsabilidad por «levantamiento del velo», IEF, 2009, pág. 115; Exigiendo más de un 50\% o más de un $33 \%$ del capital, o también dependiendo que se exija mayor participación en fondos propios, resultados o derechos de voto. GARCÍA NOVOA, C.: El Proyecto de Ley de Prevención del Fraude (II), Quincena Fiscal, núm. 10, 2006; Por nuestra parte, a título ejemplificativo, aducimos el art. 42 del Código de Comercio, donde se establece una presunción de control, siguiendo el vigente art. 18.2 (LIS) por asimilación al control en entidades con operaciones vinculadas.

${ }^{117}$ El fraude de ley al que aquí se refiere el texto legal no es el fraude a la ley tributaria, actualmente regulado en el artículo 15 de la Ley 58/2003 bajo la equívoca denominación de conflicto en la aplicación de la norma tributaria, sino el previsto en el apartado 4 del artículo 6 del Código civil, según el cual, Los actos realizados al amparo del texto de una norma que persigan un resultado prohibido por el ordenamiento jurídico o contrario a él, se considerarán ejecutados en fraude de ley y no impedirán la debida aplicación de la norma que se hubiere tratado de eludir. La razón es que el conflicto se refiere a la fase de liquidación del tributo (la Ley habla de evitar la realización del hecho imponible o minorar la base o la deuda tributaria), mientras que la responsabilidad actúa en fase recaudatoria, evitando la responsabilidad patrimonial universal.

El abuso de derecho, mencionado en el artículo 7.2 del mismo Código pero no definido por él, suele considerarse como el ejercicio de un derecho subjetivo en perjuicio de un tercero. Echevarrieta Sazatornil, J. M. ${ }^{a}$ : Los nuevos supuestos...op. cit.

118 Pérez Bernabeu, B.: Levantamiento del velo...op. cit. págs. 64-65. 
tas economías de opción que pueden perseguirse, el supuesto de responsabilidad tributaria no habrá lugar ${ }^{119}$.

El oscuro ${ }^{120}$ supuesto del apartado h) del art. 43.1. ${ }^{\circ}$ LGT [levantamiento del velo inverso] supone el desenmascaramiento de "personas o entidades»-también incluyendo los entes del art. 35.4 LGT- para alcanzar a los «obligados o infractores tributarios»; personas físicas, jurídicas o entes sin personalidad, que las han creado o utilizan como medios de elusión o limitación de su responsabilidad. En este supuesto se permite a la Administración exigir el pago del crédito o sanción a un tercero ajeno (una persona jurídica), a quien el deudor (infractor) transfirió su patrimonio de forma abusiva $o^{121}$-no $y$ - fraudulenta, siendo este supuesto bien distinto del anterior y de la doctrina del levantamiento del velo, pues, con dicha teoría se permite investigar el interior del deudor (infractor) persona jurídica, para, prescindiendo de la personificación, exigir el pago a quien la creó, administró o de quien depende, so pretexto de que son éstos los que realmente han intervenido a través de la falaz personificación, mientras que, en el supuesto $h$ ), la exigencia ${ }^{122}$ del crédito se materializa en una persona jurídica distinta y ajena al hecho que originó la deuda (o sanción), como consecuencia de la despatrimonialización deliberada del deudor (infractor), que fue quien sí intervino efectivamente en su generación ${ }^{123}$. Es decir, con esta norma se pretende luchar contra aquellas situaciones en las que el obligado pretende sustraer su responsabilidad atribuyendo - parte $\mathrm{de}^{124}$ - su patrimonio a una entidad controlada.

En ambos supuestos se demandan, cumulativa y no alternativamente $^{125}$, las siguientes circunstancias: a) Que las personas jurídicas

${ }^{119}$ Checa González, C.: Ley de Medidas para la Prevención del Fraude Fiscal, Aranzadi, Navarra, 2007, pág. 47; además incorpora la exigencia de que, junto a los elementos psicológicos, se acuda a datos o circunstancias objetivas que acompañen a las conductas humanas, ZORNOZA PÉREZ, J. J.: El sistema...op. cit. pág. 209.

${ }^{120}$ MARTÍNEZ LAGO, M. A; y ALMUDí Cid, J. M.: Autotutela...op. cit. pág. 21.

${ }^{121}$ Disyuntiva que nos lleva a tener que elegir el abuso (reiterado) de formas jurídicas o el uso fraudulento de las mismas, pero no vale argüir indistintamente ambas.

${ }^{122}$ Los principios que rigen estos aspectos de la responsabilidad en el ámbito tributario español son los de responsabilidad subsidiaria y de solidaridad, es decir, de exigencia íntegra de su cuantía a cualquiera de ellos, en los supuestos de pluralidad de responsables. ESCRIBANO LÓPEZ, F.: Notas sobre la regulación de la responsabilidad tributaria, en la obra colectiva Sujetos pasivos y responsables tributarios, Instituto de Estudios Fiscales, Marcial Pons, Madrid, 1998, págs. 590-591

${ }^{123}$ DE GANDARIAS MARTOS, S.: Las modificaciones introducidas por la Ley 36/2006 de prevención del fraude fiscal en la responsabilidad tributaria: levantamiento del velo, IEF, Doc. Núm. 26/07, págs. 22-23.

${ }^{124}$ Sánchez Huete, M. A.: El levantamiento del velo...op. cit. págs. 154 y 255.

${ }^{125}$ ECHEVARRIETA SAZATORNIL, J. M. ${ }^{\text {a: }}$ Los nuevos supuestos...op. cit. 
hayan sido creadas, originaria ${ }^{126}$ o sobrevenidamente, de forma abusiva o fraudulenta para eludir la responsabilidad patrimonial universal frente a la Hacienda pública, b) que ha mediado un abuso del uso de las formas societarias con daño al tercero que es cualquiera de las «Haciendas Públicas o Administraciones Tributarias» ${ }^{127}$; c) que concurra ya sea unicidad ${ }^{128}$ de personas ${ }^{129}$ o esferas económicas ${ }^{130}$, ya sea confusión ${ }^{131}$-aparentando insolvencia una de las personas- o desviación patrimonial ${ }^{132}$-por transferencia y sin contraprestación-, d) y

${ }^{126}$ Ejemplos sería la creación por los mismos socios de una sociedad que continúa o sucede a otra anterior (que queda inactiva de hecho o se disuelve) en la misma actividad para eludir las deudas de ésta; la creación de una sociedad patrimonial sin actividad a la que se aportan los bienes y derechos de otra o de una persona física, quedando éstos en situación de insolvencia frente a sus acreedores; la creación de sociedades ficticias sin funcionamiento real; y, la creación de sociedades unipersonales para eludir responsabilidades del ejercicio personal de la actividad económica. GIL DEL CAMPO, M.; MELLADO BENAVENTE, F. M.; y MOLINA ALGUEA, E.: La nueva Ley de Prevención del Fraude Fiscal, CISS, Valencia, 2007, 151.

${ }^{127} \mathrm{Al}$ referirse el supuesto a la necesidad de buscar eludir la responsabilidad patrimonial universal frente a la Hacienda Pública, y no hacer referencia a obligaciones de otro tipo, como las que no ocasionan perjuicio económico (arts. 198-206 LGT), v.gr. las de colaboración formal, podemos colegir que se descartará, necesariamente, la aplicación de tales supuestos de responsabilidad subsidiaria a las sanciones derivadas de infracciones formales basadas en obligaciones de colaboración. De igual parecer es SÁNCHEZ HUETE, M. A.: El levantamiento del velo...op. cit. págs. 102-103.

${ }^{128}$ Este requisito, que vendría a objetivar la prueba del propósito de abuso o elusión, parece ser que resultaría suficiente para considerar probada la intención fraudulenta, aunque existen riesgos de una aplicación automática a supuestos en los que no resulte justificado aplicar esta doctrina. Así SOLER ROCH, M. ${ }^{\mathrm{a}}$ T.: Lifting...op. cit. págs. 842-844.

${ }^{129}$ La unicidad de personas se basa en la realización de una misma actividad económica a través de sociedades que van siendo sustituidas a medida que van generando deuda tributaria. El negocio siempre es el mismo y también lo es quien se lucra con él.

${ }^{130}$ La unicidad de esferas económicas supone la fragmentación de una actividad económica en varias partes desarrolladas por distintas personas, de forma que la deuda tributaria se residencie en aquella que carece de bienes o derechos embargables por la Administración.

${ }^{131}$ El desvío de fondos del deudor a sociedades patrimoniales, se da con el fin de aparentar insolvencia conservando, al mismo tiempo, el control de su patrimonio que queda a salvo de la actuación recaudatoria. La desviación patrimonial ha de consistir en la transferencia de recursos económicos del patrimonio del deudor al de la sociedad controlada por él. La exigencia de la responsabilidad implicará la prueba de tal transferencia que, además, deberá producirse sin contraprestación real, pues de otro modo no se produciría la insolvencia que determina la elusión de la responsabilidad patrimonial universal.

${ }^{132}$ Lo que puede generar problemas en caso que el funcionario entienda producidas dichas circunstancias y no lo haga de igual modo un juzgador, p.ej. mercantil, obviando así un tratamiento unívoco a un instituto proveniente del derecho privado. 
que exista una voluntad rectora común entre las personas ${ }^{133}$ físicas y jurídicas que participan del entramado patrimonial. En conclusión, la diferencia entre ambos supuestos es que el primero [letra g)] establece la responsabilidad de las personas que utilicen una persona jurídica para eludir la responsabilidad patrimonial universal frente a la Hacienda Pública, y el segundo [letra h)] es el envés de la moneda, la responsabilidad de las entidades creadas o utilizadas abusivamente con la citada finalidad ${ }^{134}$.

De igual modo en ambos supuestos, pese a nuestro parecer de inviabilidad ${ }^{135}$ de hacer responsables tributarios, y menos subsidiarios, en el pago de sanciones tributarias de personas ajenas, de seguro lo que sí se colige es que las sanciones de las que se sea responsable deben ser las que abarquen el ámbito temporal, o lapso, en el que se tenga el dominio o control por cada uno de los responsables, ni anteriores ni ulteriores.

No debemos acabar este comentario sin recordar ${ }^{136}$ que la práctica totalidad de las conductas que se pretenden perseguir con estos mecanismos legislativos son de dudosa constitucionalidad ${ }^{137}$-lo que claramente se colige, al menos, del art. 43.1.h) LGT-, y si se prueban, son insolvencias punibles tipificadas en los arts. 257 a 261 del Código Penal, de manera que, o bien se ha cometido un delito ${ }^{138}$, en cuyo caso la Hacienda Pública no puede actuar -salvo que pretenda ilícitamente hacerlo (en uso de una pseudo-facultad discrecional ${ }^{139}$ ) al margen del proceso penal, y con una probática más laxa- ${ }^{140}$, o bien no existe voluntad de impedir la eficacia de un embargo administrativo, en cuyo caso no puede exigirse la deuda ni la sanción a una persona distinta del obligado.

${ }^{133} \mathrm{El}$ problema de la exigibilidad de esta responsabilidad se acrecentará en la medida en que intervengan personas físicas o jurídicas extranjeras.

${ }^{134}$ RUIZ ALMENDRAL, V.: El levantamiento del velo ...op. cit., pág. 1044.

${ }^{135}$ Como ya indicamos, entre otros, por el principio de personalidad de las penas y sanciones. De ese parecer son Martínez Lago, M. A; y Almudí Cid, J. M.: Autotutela...op. cit. pág. 21.

${ }^{136}$ FALCÓN Y TELLA, R.: Otras medidas ...op. cit. págs. 9-10.

${ }^{137}$ Por su redacción ambigua e imprecisa. Falcón y Tella, R.: Otras medidas ...op. cit. págs. 9-10; Por ser contrarios a los principios de seguridad jurídica y tutela judicial efectiva (arts. 9 y $24 \mathrm{CE}$ ). Soler Roch, M. ${ }^{\mathrm{a}}$ T.: Lifting...op. cit. pág. 839.

${ }^{138}$ SÁNCHEZ HUETE, M. A.: El levantamiento del velo...op. cit. pág. 292.

${ }^{139}$ A modo de facultad discrecional de la Administración Tributaria excesiva e inadecuada. CHECA GONZÁLEZ, C.: Ley de Medidas ...op. cit. pág. 48.

${ }^{140}$ En estos supuestos, la Administración estaría obligada a denunciar ante la autoridad judicial, y al amparo del art. 289 LECrim...la responsabilidad subsidiaria estaría condicionada directamente al resultado del proceso penal. De Gandarillas Martos, S.: Las modificaciones...op. cit. pág. 21. 
